\title{
Archaeological Studies of Cooking and Food Preparation
}

Sarah R. Graff, $1 \bowtie$

Phone 480-727-5490

Emailsrgraff@asu.edu

1 Barrett, The Honors College, Arizona State University, PO Box 871612, Tempe, AZ, 85287-1612 USA

\section{Abstract}

Foodways have been a component of archaeological research for decades. However, cooking and food preparation, as specific acts that could reveal social information about life beyond the kitchen, only became a focus of archaeological inquiry more recently. A review of the literature on cooking and food preparation reveals a shift from previous studies on subsistence strategies, consumption, and feasting. The new research is different because of the social questions that are asked, the change in focus to preparation and production rather than consumption, and the interest in highlighting marginalized people and their daily experiences. The theoretical perspectives the literature addresses revolve around practice, agency, and gender. As a result, this new focus of archaeological research on cooking and preparing food is grounded in anthropology.

AQ1

\section{Keywords}

Cooking

Food preparation

Cuisine

Practice

Agency 


\section{Gender}

\section{Introduction}

Now more than ever before, it is important to survey the kind of research we are producing on cooking and food preparation. More people are interested in food and how people prepared it in the past. Health gurus, nutritionists, journalists, and the public at large are interested in learning more about how our ancestors ate and what, if anything, has changed in our food supply (such as the genetic mutations of wheat for those concerned about allergies) and also in our diets and how they were prepared. Calls for a (purer) diet that is connected to a more pristine past, presumably healthier than our current diets, should be a call for archaeologists to step in and discuss this Rousseauian nostalgia, as well as misconceptions about foodways in the past. The Paleodiet is a great example of a diet that has been marketed as "better" and "healthy" because it follows a formula that was purportedly the diet of "our ancestors." Archaeologists can contribute to these public discussions and offer information from deep history, over long periods of time and across geographical spaces, something the marketing teams and even the food historians are unable to offer.

Food and the variety of human activities that intersect with food have been important foci for archaeological research for the last 30 years. Recently, increasing numbers of archaeologists are studying cooking and food preparation as specific practices that reveal social information beyond subsistence, tool inventories, or activity areas. Over the past six years alone, four edited volumes using archaeological methods to investigate cooking in the past have been published (Graff and Rodríguez-Alegría 2012; Klarich 2010a; Mee and Renard 2007; Spataro and Villing 2015), and two special issues of journals explore food and its preparation from an archaeological perspective (Gokee and Logan 2014; Pollock 2012). Conference panels have been organized (Kooiman 2017; White and Ketchum 2014), and numerous articles that examine cooking and food preparation archaeologically and explore interpretations beyond traditional views are in press. This is a new and, I would argue, productive approach. In earlier studies, the focus was on 
food for subsistence purposes, or food as part of the domestic economy. Subsequently, there was an emphasis on feasting and consumption (for discussions of these earlier studies see Cuéllar 2013; Mintz and Du Bois 2002; Montón Subías 2002; Rodríguez-Alegría and Graff 2012; Twiss 2012a). These emphases were constructive, pushed archaeologists to think differently about data, and generated new questions for archaeologists to address. Along with studies on food consumption, some archaeologists were writing about food preparation, and these studies influenced those who are currently writing about cooking and food preparation archaeologically (e.g., Brumfiel 1991). But, I argue, a newly developed, specific interest in cooking and food preparation and what it can tell us about society, economy, politics, and religion in the past has emerged in the literature of late. This new, productive approach is valuable for illuminating a variety of social practices, such as how people negotiated social differences and power relations in the past, how cooking might be connected to statecraft, how religious beliefs might be revealed through cooking, how changes in the craft of cooking is related to technological change, and how cooking practices effect economics. This interest in a specific avenue of research opens a new chapter in the study of humans and food.

Why are archaeologists looking into past practices of cooking and food preparation more closely? The study of cooking and food preparation helps us identify ways in which everyday practice changes and/or continues in the political, economic, religious, and sociocultural realms. Meals structure the lives of those who prepare food and those who consume food, creating a foundation for social life (Atalay and Hastorf 2006, p. 283). As Villing and Spataro (2015, p. 1) note, cooking and food processing is an aspect of social and cultural identity and a fundamental part of social life. Rodríguez-Alegría and Graff $(2012$, p.1) argue, "studying cooking activities can provide a window into other aspects of society, such as relations of power in public and private contexts, politics, economics, religion, social change, cultural practice, and social identity." Past cooking practices also provide a window into the more quotidian aspects of food, not just the less common occasion of the feast (defined by Dietler [2001] as opposed to Hayden [2014]). A research focus on more regularized food preparation and cooking practices 
does not ignore feasting; on the contrary, it includes this body of work and can compare cooking in different contexts to highlight differences, variations, and similarities in each context (Twiss 2012b). A focus on the daily aspects of food preparation also can help highlight and answer questions about the people who do this work. They may or may not have been credited for the kind of work they did, and many aspects of their lives may be unknown. These are the very people who are most often omitted from historical texts, and archaeological research offers the best means for uncovering their past.

Feminist archaeology brought the notion of social difference and the treatment of different social groups to the forefront of archaeological thinking (Geller 2009; Gero and Conkey 1991; Hendon 2007), and research on cooking and food preparation is emerging, in part, from this tradition. This does not mean that all archaeologists who study cooking and food preparation take a feminist position, or even discuss gender in their research; it does mean that work on cookery and food preparation concerns feminist theory, by the simple fact that due to their own biases most researchers assign cooking and other household chores automatically to women. The concern also stems from the neglect of culinary labor prior to these current studies because such labor was considered unimportant (González-Marcén et al. 2008; Montón Subías 2002; Rodríguez-Alegría and Graff 2012). In fact, archaeologists working on Pueblo sites routinely discarded artifacts of women's culinary labor (Heitman 2016). Similar acts of discarding cooking wares, sometimes described as "crud ware," have happened in many excavations around the world. Studies of cooking and food preparation, in some cases, are dealing with these problems of omission and opening the discussion to the wider archaeological community.

To organize the literature for this review it was necessary to create parameters, and they are imperfect. First, to narrow the focus, I primarily assess research written in English. I recognize that this review is geared toward a particular audience, and I hope that someone will review the nonEnglish literature on cooking and food preparation in the future. Second, I do not discuss human behavioral ecology or evolutionary ecology models because most of this body of work focuses on subsistence strategies rather 
than food preparation explicitly (for a recent discussion see Hayden 2014). Third, I focus less on alcohol in favor of other foods and drinks. This is in part to limit the scope of the analysis, but I also want to highlight areas of research that may have garnered less attention from archaeologists in the past.

This article reviews recent work on cooking and food preparation by archaeologists. I mainly review publications between 2005 and 2016, synthesizing what characterizes this body of literature and how it has advanced our understanding of human relations in the past. I point out the theoretical perspectives that have coalesced from this focus on cooking in the discipline, discuss new scientific techniques that allow archaeologists to analyze food preparation data in new and productive ways, and then highlight specific themes that emerge from a survey of the literature. Finally, I offer ideas on some gaps in current analysis and propose new directions for research. I argue that the recent trend in examining cooking and food preparation in context, especially because of the interest in highlighting marginalized people and their daily experiences, is distinctly different from previous studies on subsistence strategies, consumption, and feasting.

\section{Theoretical Trends}

Archaeologists working on cooking and food preparation, either as a focus for their research or as part of a larger program, draw from a diverse set of theoretical explanations and methods. Three theoretical perspectives ground the archaeological literature on the preparation and cooking of food: practice, agency, and gender. While I do not think all the current research fits neatly into these three arenas, I do see that these ways of thinking directly affect the literature. These three concepts are intertwined in one way or another by those who study cuisines and their preparation in the past. AQ2

\section{Practice}

One of the more popular ways to theorize cooking and food preparation is through a practice theory approach. This approach focuses on how people were cooking, the choices that they made, and how the actions involved in 
processing foods were either part of daily routines or part of something that did not happen regularly. The goal of this approach is to highlight sociocultural, political, and economic information, and their relationships, in context. Archaeologists who use a practice theory approach examine daily meals as they structure the lives of individuals and groups, examine tools and ingredients, reconstruct the order and relationships between different tasks, and investigate culturally valued methods for preparation and timing of the tasks involved. Some archaeologists use Bourdieu's (1977) concept of habitus to explain why the act of cooking could be viewed as an unspoken cultural capital, as an aspect of structure to daily life, and a way to continuously reproduce social life (Ashley 2010; Atalay and Hastorf 2006; Gifford-Gonzalez 2008; Hastorf 2012a; Pezzarossi et al. 2012; Sunseri 2015). Others are interested in using a relational approach to look for ways that people performed different but related productive tasks, such as cooking and ceramic production, how those tasks might have shared certain practices, and the social connections between those activities (Gokee and Logan 2014; Goldstein and Shimada 2010; Logan and Cruz 2014; Stahl 2014).

Some researchers view the actions involved in processing food, the tools used to facilitate those actions, and the choice of ingredients as a type of technology. Changes in the actions, tools, or choices could be viewed as a change in technology (Lyons 2007). Similarly, since some of the literature focuses on cooking and preparation tools, such as cooking pots or grinding stones, it is not uncommon for at least some aspect of those studies to focus on the production and/or technological aspects of those tools (Ashley 2010; Graff 2012; Hamon and Le Gall 2013; Müller et al. 2015; Winther-Jacobsen 2015). As a result, many scholars who use a practice-centered approach cite and align their work with research on technology and technological choices, even more specifically with the literature that explicates and uses the concept of chaîne opératoire or sequence of operations (Lemonnier 1993; LeroiGourhan 1993). The chaîne opératoire requires that the archaeologists work to reconstruct the actions a producer performed to make something, such as discovering the ingredients a cook used, the order in which they prepared the items of food, where they cooked, the tools they used, and the gestures they made to execute their actions. Examining the chaîne opératoire makes it 
possible to look for and consider the choices made by those who were cooking and preparing food. Repeated food preparation gestures and actions with specific tools, and the sequences in which they occurred, it is argued, both make and reproduce cultural identities and social distinctions that are archaeologically identifiable (Arthur 2014; Ashley 2010; Chase 2012; Gifford-Gonzalez 2008; Grillo 2014; Hamon and Le Gall 2013; Lyons 2014; Russell and Bogaard 2010; Villing and Spataro 2015; Winther-Jacobsen 2015), especially when they are compared to related, contextual tasks such as cooking and pottery making (Logan and Cruz 2014).

Thinking about cooking and food preparation as a form of craft, some archaeologists use Costin's (1991) models for the study of craft production to discuss the preparation of food (De León 2009; LeCount 2010). While these studies do not discuss practice theory or the concept of chaine opératoire, they explore the intersections between the making of inedible things and the making of edible things.

\section{Agency}

A focus on agency, especially the individual agency of the cooks, or the social groups who do the cooking, is also prevalent in the literature.

Sometimes archaeologists discuss the concept of agency in tandem with practice theory, explicitly linking Bourdieu (1977) and Giddens (1984). Researchers might use the chaîne opératoire concept and its focus on choices to discuss agency (Russell and Bogaard 2010). Often agency is discussed within the context of research on identities (for a detailed discussion see Twiss 2012a). For example, Urem-Kotsou and Kotsakis (2007) point out the complex and subtle picture of social differentiation through individual cooking and consumption styles. The cooking literature that discusses agency focuses on the intentional actions of those preparing and cooking food, including the choice of ingredients, tools, or serving vessels. Turning materials into culturally acceptable food is an active process that involves individual agents, their knowledge, and a variety of limitations the agents must acknowledge. Archaeologists discuss how cooks must know their job not only to produce food that people will consume, but also how to make food that will be culturally digestible. This experience positions the cook as 
one with skill, knowledge, and power that is at once personal and social. This powerful cook could choose to incorporate some foreign elements into a cuisine (Dietler 2010a; Jordan 2015), or adopt indigenous foods but redefine them (Dawdy 2010; Scaramelli 2008), create or reinforce identities (Lyons 2007; Magness 2010; Mills 2008; Pezzarossi et al. 2012; Reddy 2015; Smith 2003; Urem-Kotsou and Kotsakis 2007), express resistance (Deetz 2015; Mills 2008), and forge ties (Sunseri 2015).

\section{Gender}

Another important theoretical theme that informs the archaeological studies on cooking and food preparation is gender. It is standard fare to look at gender in studies that involve preparing and cooking food. This is because of assumptions about women's work, material culture, and spaces stereotypically associated with women, and the uncritical use of ethnographies or ethnohistoric sources that depict women doing the work of food preparation and cooking (see Brumfiel and Robin 2008; GiffordGonzalez 2008). On the one hand, this has been an important way to bring women into discussions about past practices, discussions that women were largely absent from for a long time. On the other hand, the assumptions about gender roles and identities that Brumfiel and Robin (2008, p. 1) wrote about stand firm in the literature. The construction of gender as a male/female binary, and the social values placed on that binary in the archaeological literature, especially with regard to labor, has not changed even though most archaeologists would agree that gender identity is not tied to biology. While feminist archaeology would work well in studies of cooking and food preparation, most of this research to date does not take an explicitly feminist position. Feminist theory argues that gender is socially constructed, not biologically determined, and therefore variable. A feminist approach is political because it addresses unequal power structures in society with the goal of changing systems of oppression. It also looks for ways that different identities intersect with gender and how social, political, economic, or religious life might be affected by those intersections (see discussions in Brumfiel and Robin 2008; Geller 2009; Gifford-Gonzalez 2008; Hays-Gilpin 2000; Nelson 2006). The current studies of cooking are poised to contribute to feminist archaeology because many researchers are looking for evidence 
of marginalized groups, and looking at the intersections of identity, such as through the comparison of cooking and craft production. However, much of the literature currently discusses gender detached from feminist theory.

Looking for social intersections with gender was exactly how Brumfiel $(1991,1998)$ argued that women's work in central Mexico before and after Aztec domination varied, including food preparation techniques. She argued that although women were the ones who cooked (based on the rich ethnohistoric documentation), the way they cooked, and the tools they used most, differed depending on their family needs and other work for which they were responsible. At sites in the Valley of Mexico, where families worked away from home tending agricultural fields, gathering fuel, and going to the market, cooks used more tortilla griddles. Tortillas were portable, and with family members spending time away from home, sending them off with food was important. In addition, the women had access to markets to purchase cloth so they were not concentrating their work on weaving. In Morelos, also in central Mexico, the cooks used cooking pots more frequently to prepare stews, which required less constant attention and needed to be eaten at home. The women in Morelos wove more tribute cloth because they did not have access to a market where they could purchase cloth. If Brumfiel had not compared cooking and weaving at a number of sites in central Mexico, she would not have been able to see the intersections of social, political, and economic life with gender and work. Many who research cooking are influenced by Brumfiel's pioneering work. Recent studies compare the production of specific crafts with food preparation, searching out the relationships between tasks and what they might mean for people with different identity categories (Arthur 2014; Gokee 2014; Gokee and Logan 2014; Logan and Cruz 2014; Lyons 2014; Monroe and Janzen 2014; Stahl 2014). Similarly, researchers use multiple lines of evidence to compare different kinds of food preparation practices and their intersection with gender and other identities (Atalay and Hastorf 2006; Costin 2016; Dawdy 2010; Deetz 2015; Djordjević 2016; Hastorf 2012a; Jones and Quinn 2010; Mills 2008; Pezzarossi et al. 2012; Rodríguez-Alegría 2012;

Scaramelli and Scaramelli 2012; Stein 2012).

Work on cooking and food preparation was lacking until recently because the 
job of the cook was not considered important. Transforming ingredients into edible food was considered domestic work, performed in the home by women, and therefore divorced from the power, politics, and economics of other, more socially valued work (Gifford-Gonzalez 2008; González-Marcén et al. 2008; Klarich 2010b; Rodríguez-Alegría and Graff 2012; Montón Subías 2002). The new emerging research that examines cooking and food preparation challenges this outlook on what was (and is) socially valued. Since all action is meaningful, as proposed by practice theory and agencybased models, this new research helps move archaeology forward by exploring this previously unchartered territory.

\section{Categories of Data and Methods}

Studying cooking and food preparation does not necessarily require a different tool kit from other archaeological research. However, literature focused on the preparation and cooking of food reveals that successfully addressing social questions requires multiple sets of data and therefore increasingly requires collaboration among specialists.

Archaeologists who examine cooking and food preparation are working to balance their own observations of archaeological data with the intentions and meaning of the actors who left evidence of their actions behind. Capturing the traces of past actions is a primary concern, but looking for what was meaningful to the actors, from their perspective, is also a research goal. Many researchers also are interested in past actors that might not have been captured by historical records. To achieve these goals, those who study cooking and food preparation in the past use a combination of ethnoarchaeology, ethnohistory, experimental archaeology, and scientific analyses in their research.

\section{Ethnoarchaeology and Ethnohistory}

Ethnoarchaeology is widely used and has been combined often with other methods of research. It is not just a method (for a discussion on the production and use of ethnoarchaeological data see Chirikure 2016; Hamilakis 2016), and archaeologists who use ethnographic analogy as a heuristic device to understand cooking and food preparation in the past do so 
with many caveats, such as not assuming cultural continuity. But, it is considered an important component of archaeological research in the literature. Some ethnoarchaeological research concentrates on the production of cooking vessels (Day et al. 2015; Djordjević 2016; London 2016; Nabil 2015), and other research illustrates different activities and the people involved in cooking and food preparation (Hayashida 2008; Jones 2009; O’Conner 2010; Smogorzewska 2012; Tuma 2006), sometimes in combination with the production of cooking vessels, food preparation tools (Arthur 2014; Gokee 2014; Hamon and Le Gall 2013; Logan and Cruz 2014; Lyons 2007, 2014), or cooking installations (Gur-Arieh et al. 2013).

The ethnohistoric method, and the analysis of texts more broadly, also is widely used and combined with other methods. For specialists working in Mesoamerica, documents written in local scripts, images, indigenous codices, and colonial period documents all contribute significantly to knowledge on food and cuisine (Staller 2010). In other parts of the world, and in other time periods, when texts (in the broadest sense) are available, contributions come from ancient ration lists, written reports, ethnographic accounts, and graphic depictions of food preparation such as grinding grain. Textual evidence is often employed to contextualize archaeological data on cooking and food preparation (Gokee 2014; Graff 2012; Hawkes 2015; Hruby 2008; London 2016; Pezzarossi et al. 2012; Rodríguez-Alegría and Stoner 2016; Scaramelli and Scaramelli 2012; Thoms 2008), including native ontologies (Bray 2012).

\section{Experimental Archaeology}

Experimental archaeology is another popular method employed in research on food preparation. When archaeologists find the remains of food processing, it is not always clear exactly how people in the past used their tools, made their food, or how other tasks might have helped or hindered the cook. Many archaeologists interested in the different actions, ingredients, and tools involved in preparing food use experimental archaeology to learn more about different choices and steps in processes that may no longer be visible. Some researchers use experiments with food and tools to look for identifiable ways that certain food preparation techniques might be visible 
archaeologically (Carretero et al. 2017; Capparelli et al. 2015; Dezendorf 2013; Disspain et al. 2016; Fernandes et al. 2014; Graesch et al. 2014; GurArieh et al. 2012; Hart et al. 2007; Henry et al. 2009; Müller et al. 2013; Pecci et al. 2013; Raviele 2011; Simms et al. 2013; Thoms 2008; Warinner and Tuross 2009). For example, Morrison et al. (2015) combined experimental archaeology with ceramic analysis and archaeological, zooarchaeological, ecological, and ethnographic data. Based on research from the Late Minoan site of Papadiokampos in Greece, they made and prepared replica cooking pots, working to replicate the ancient techniques, and cooked a variety of food inside the pots corresponding to what was found archaeologically. They discovered that such skills as timing the preparation and cooking of different foods mattered for the successful outcome of the meal and that blackening of the cooking pots did not occur even when they were used multiple times to cook food inside the hearth. Their archaeological assemblage from hearth contexts also was not blackened, indicating that cooking pots were not always blackened by use (Morrison et al. 2015). In another example, a different combination of methods was used to learn more about bread baking pans from the Balkan region that had been made and used by women for generations. The manufacture and use of these ceramic pans had been discontinued about 30 years ago (Djordjević 2016). In addition to ethnographic interviews, Djordjević and her collaborators found women who had knowledge of making and using bread baking pans in eastern Serbia to help recreate the process. Djordjević (2016, p. 318) called it an "ethnoarchaeological experiment."

Experimental archaeology also has been fruitful in more sensorial ways as well, by allowing researchers and others to taste the past, so to speak, and embody the ancient ways of food preparation, brewing, or cooking. The layperson is familiar with these experiments through news articles on reconstructing ancient beer recipes (Killgrove 2016), tasting events (Alderfer 2016), and even the recreation of ancient menus (Koca 2015). Some archaeologists have teamed up with modern brewers to work on the process and produce beer for modern consumers who are interested in tasting the past (Paulette and Fisher 2014; Pitock 2015). In addition, a growing number of 
scholars are translating ancient recipes and working on either recreating the dishes for modern cooks on their own, or working with modern chefs to resurrect them (Faas 2003; Kelly 2012).

\section{Paleoethnobotany and Zooarchaeology}

Scientific analyses are another set of methods archaeologists employ to access data on food preparation and cooking. The most commonly used are paleoethnobotanical (for a review on paleoethnobotany and food preparation see VanDerwarker et al. 2016) and zooarchaeological (deFrance 2009) because these methods often access prepared food directly, and many excavations already have dedicated specialists who use these methods to answer questions. One aspect of paleoethnobotany is the analysis of microbotanicals, such as phytoliths, where microfossil remains from edible plants are identified archaeologically to learn more about food processing (Cummings 2015). A variety of soil microtechniques also are used to find evidence for food processing and cooking, including chemical analysis and micromorphology (Miller 2015). Starch grain analysis is another method used to identify food processing techniques and the tools that were used (Crowther 2012; Yang et al. 2009). If people processed starches such as nuts, tubers, roots, or seeds, the starch left behind often adheres to the tools and can be recovered for analysis. Although palynology is commonly used to identify wild and cultivated plants, pollen washes of archaeological tools such as manos and metates also are used to identify plant processing (Geib and Smith 2008). Examining both the composition and the microstructure of charred food yields information on food preferences, processing techniques, and cooking practices (Carretero et al. 2017; Heiss et al. 2015).

Zooarchaeologists can identify different animal taxa, differentiating between domestic animals, wild animals that were hunted, and exotic animals. The choice of animal, and possibly the particular cut for consumption, might indicate a social distinction, such as a hierarchical relationship or a religious practice. It also is possible to determine the age and sex of the animals, the number of animals consumed, the different body parts and their frequency, butchering techniques on bones, and the method of cooking, such as roasting or boiling (deFrance 2009; Russell 2011). This research makes it possible to 
discuss social relationships and values in the past because human choices are visible in the evidence from the bones of consumed animals.

\section{Analytical Methods}

Residue analysis is one technique used to learn about food processing. Residue analysis, including gas chromatography/mass spectroscopy, can identify what foods were cooked inside a vessel (Craig et al. 2015; Pecci et al. 2015; Roumpou et al. 2007). Analyses of absorbed plant or animal residues left behind on tools are an important way for archaeologists to study food preparation and cooking practices (Evershed 2008; McGovern and Hall 2015; Roffet-Salque et al. in press). In addition to identifying specific foods people were cooking and eating, residue analysis of different tools used over time, or the same tools used within one region contemporaneously, can help archaeologists identify changes in cooking practices over time, or a singular cuisine that links different sites in a region together. For example, Cramp et al. (2011) analyzed Roman mortaria, a type of bowl used to mix culinary ingredients, and found that they were used to prepare plant and animal products reflecting a new aspect of the cuisine at the time.

A sister method to residue analysis is use-wear or use alteration analysis; it also helps identify cooking practices and changes in those practices over time. In the case of cooking pots, the analyst looks at the patterns of carbonization on the exterior and/or the interior of a pot to identify the methods of cooking, as well as wear patterns from repeated actions such as stirring (Skibo 2015). Archaeologists can examine other tools made from stone, metal, or ceramic to look for characteristic patterns and identify how those tools were used by people to prepare food in the past.

Stable isotope analysis is another important tool for identifying diet. Isotopic analyses on human tissue show what people consumed, so comparing these data to data on food processing and production helps mitigate issues of material preservation in different contexts. An example is a study by Olsson and Isaksson (2008), who compared human bone remains and lipid residues in pottery from a site in medieval Sweden. They found evidence in the human remains of fish consumption but did not find fish was cooked in the 
pot. This discrepancy illustrates the importance of applying several analytical techniques to reconstruct food preparation because reliance on only one might lead to incorrect inferences. Warinner and Tuross (2009) conducted a study that used stable isotope analysis to examine food preparation. Combining the experimental approach with stable isotope analysis, they looked at the isotopic ratios of pigs that consumed maize prepared by nixtamalization or alkaline cooking, where dried maize kernels are soaked and boiled in an alkaline (such as lime) water solution. They found that alkaline cooking did in fact affect the isotopic ratios of the pigs, which could in turn affect the nutrition of the people who ate the pigs (Warinner and Tuross 2009).

Other scientific techniques use microscopy to access new information on cooking. For example, Koon et al. (2010) used transmission electron microscopy (TEM) to sort butchered meat from boiled meat. Considering the bones of the meat, Solari et al. (2015) looked for ways to identify bones cooked at low temperatures. They compared macroscopic techniques to physicochemical techniques and specifically demonstrated that different methods of cooking change the structure of bones. Examining the microstructures of charred food remains using SEM (scanning electron microscopy), especially in conjunction with experimental archaeology (Carretero et al. 2017) or chemical analysis (Kubiak-Martens et al. 2015), helps identify particular foods and how they were cooked. Without charring, starch grains can be difficult to see. However, Lamb and Loy (2005) identified preserved starch grains by using congo red as a dye to make them visible under the microscope. This technique makes it possible to find evidence for cooking beyond charred remains. Micromorphology also is used to learn more about the variety of hearths and earth ovens (Mentzer 2012). Finally, computer models and simulations have been used to test the effects of different cooking methods on pots (Hein et al. 2015).

Most researchers who study cooking and food preparation consider multiple lines of evidence drawn from more than one method. This is especially true in cases where historical texts are not available, but even when texts are available, archaeologists are not relying on them alone. The authors make the argument that the only way to demonstrate social processes in context would 
be to mobilize a variety of telling data (Black and Thoms 2014). Combining ethnohistoric, ethnoarchaeological, and archaeological data, Gokee (2014) argues that women in Upper Senegal engaged with the political and economic changes during the second millennium AD through their participation in gendered practices like cooking and making pots. In another example, the combination of ethnoarchaeological research and residue analysis resulted in the discovery of traces of recognizable food preparation activities both inside and outside a structure in Morocco (Pecci et al. 2016). Cheetham (2010) combined botanical evidence, isotopic analysis of human bone collagen, ceramic analysis, agricultural production and caloric intake estimates, and other archaeological data to argue that there was a connection between culinary tools and the size of the consumer group. Another example of interdisciplinary collaboration comes from Jones and Quinn (2010), who combined zooarchaeological, ethnoarchaeological, and paleoethnobotanical data as well as data from stable isotope analysis to explore food customs in Fiji. While most of their food preparation discussion comes from ethnographic information, they found that the isotopic data agreed with the archaeological and ethnographic data, suggesting that ethnographic analogy could be a powerful tool for future interpretations in this part of the world. Homsey et al. (2010) combined paleoethnobotany, zooarchaeology, geoarchaeology, and experimental archaeology to reconstruct the cooking and food processing activities at Dust Cave in Alabama. Finally, Cau Ontiveros et al. (2015) combined an ethnoarchaeological study of potters and their work in western Italy with a compositional analysis of their wares, something the authors call "ethnoarchaeometry."

\section{Themes in Cooking and Food Preparation Literature}

Archaeologists explore complex social problems with a focus on cooking and preparing food, and the key themes that emerge from the literature highlight this aspect of the research. These themes include daily practice or events; craft production and culinary practice; identities and culinary labor; social boundaries, culture contact, and colonialism; crossing boundaries and constructing community; cooking and ritual; and finally, politics and economics. These themes naturally intersect with each other, just as culinary 
labor is integral to craft production and culinary practice. The literature does, however, treat these themes in unique ways, so I separate them to illustrate and expose the debates in the literature more fully.

\section{Daily Practice or Events}

One interesting and fruitful tension that has emerged from studies on food more broadly in archaeology is between what people do daily and cook regularly for their food, in contrast to the preparation and cooking involved in events or irregular practices. Daily practices are considered habitual for a group or part of everyday life. Events, on the other hand, emphasize something that is different from the everyday, perhaps special, part of a ritual, or practiced irregularly. Until recently, both daily food practices and events were analyzed in large part by examining the remains of consumption rather than evidence for cooking and food preparation for the meals (see discussions in Potter 2010; Twiss 2012a). A focus on consumption grounds interpretations of daily meals and events in temporal and spatial assumptions, in addition to those about scale, which are highlighted by more recent research (Lewis 2007; Twiss 2012b).

Since the publication of Dietler and Hayden's (2001b) book on feasting, a popular research focus is on events, especially articulating the social, political, and economic importance of feasts (Bray 2003a; Dietler and Hayden 2001b; Hayden and Villeneuve 2011; Jennings et al. 2005; Jones 2007; Mills 2004; Pauketat et al. 2002; Wright 2004). Dietler and Hayden (2001a, p. 3) point out that the distinction between feasts and daily meals serves as a way to identify the social meaning of this specific type of event. Klarich (2010b) reiterates this point, explaining that it is important to use the analysis of daily meal preparation to better understand feasting preparation practices. Twiss $(2008,2012 \mathrm{~b})$, on the other hand, points out that a dichotomy between daily practices and feasting obscures the relationships between the two, such as the parallels in relational power structures, or ideological parallels. According to Bray (2012), the resulting social constructions that emerge from both daily and event commensality are similar, and in some cases only the individuals participating in the shared experience might be different. 
Lewis (2007) explains how an analysis of both daily food preparation and feasting is the only way to understand the nuances of south Arabian identity articulations, because animals that were sacrificed for political rituals in South Arabia held symbolic value, which could be learned only when contrasted with their use in daily life. Yet in another perspective, both Pollock (2012) and Delgado and Ferrer (2011) argue that contrasting feasts with everyday meals could cause the daily act of preparing and consuming food to seem mundane, even biological, relegating the daily meal, and perhaps the cook, to a less important status. What this debate suggests is that equal attention to both daily food preparation and special cooking events, in context, is essential. A focus on cooking quotidian meals should not be used in support of research on special meal preparation, but rather should weigh each dataset with equal vigor and import.

The literature on feasting and daily food preparation highlights problems in distinguishing between the two types of meals in some contexts. At the Neolithic site of Çatalhöyük in Turkey, while feasting evidence was found (Martin 2000; Russell and Martin 2012; Twiss 2012b), no public buildings or public consumption areas were identified (Twiss 2012b), and researchers working there explain that some public feasting activities were incorporated into and memorialized within individual homes (Russell and Martin 2012; Twiss 2012b). At the Wari colony of Cerro Mejía in southern Peru, Nash (2010) concludes that a combination of smaller gatherings, food prepared for workers by their own families, and larger meals cooked by the women related to the group leaders all fueled the extensive labor required to create the Wari built environment between AD 600 and 800. In this case, the daily meals were just as much a part of the commensal politics as a larger feasting event. Similarly, at the 14th/13th century BC site of Tall Bazi in Syria, a comparison of houses to the temple building reveals blurry lines between daily food preparation and ritual food preparation. For example, bread and beer were produced in individual homes for both household consumption and for ritual use in the temple (Otto 2012; Sallaberger 2012). Goldstein and Shimada (2010) discuss another example from Huaca Sialupe on the north coast of Peru between AD 950 and 1050. They explain how food produced for individuals in the household was not very different from food produced 
for more communal consumption. In addition, food, especially corn beer, was regularly, perhaps daily or weekly, produced for the extended household to celebrate events or festivals in the same location as regular meal preparation (Goldstein and Shimada 2010). Hastorf (2012b, p. 217) notes that since many societies saw activities related to food consumption as sacred, archaeologists must, "work more discursively ourselves with meal variants and what they might have meant in their settings." She described how cooking methods and exotic ingredients were a significant aspect of archaeologically identifying feasts from daily meals in the Lake Titicaca Basin of Bolivia between $1500 \mathrm{BC}$ and AD 600. Daily meals consisted of boiled soups and stews, and while those foods were offered during feasts, the special meals also included steamed meat and fish. These examples demonstrate that the distinction between daily and special meals is difficult to discern in some contexts, yet vital to archaeological interpretation. AQ3

The social meanings of feasting events begin with and are framed by daily meals. Recent research trends point to an articulation of cooking and food preparation practices in the context of everyday life, in addition to events over time (Goldstein and Hageman 2010; Halstead 2012; Hastorf 2012b; Junker and Niziolek 2010; Kennedy 2012; Otto 2012; Twiss 2012b; UremKotsou and Kotsakis 2007). One way archaeologists highlight food preparation for events is to compare the data from both special function and quotidian contexts (Craig et al. 2015; Delgado and Ferrer 2011; Goldstein and Hageman 2010; Haaland 2012; Hastorf 2012b; Junker and Niziolek 2010; Masson 1999; Otto 2012; Russell and Martin 2012). Archaeological attention to the different manners and contexts of food preparation is essential, not only for understanding daily life in the past, but also for understanding political strategies, economic transactions, choices, ritual practices, and cultural values.

\section{Craft Production and Culinary Practice}

Many archaeologists examine the various interconnections between making food and the production of material culture. There are two different approaches to thinking about crafting and cooking. One approach is to look 
for socially embedded relationships between the job of making crafts and the job of cooking (Gokee and Logan 2014). Another approach is to look specifically at the tools involved in cooking and analyze them based on their use(s), whether or not they were valued, technological changes over time, and their material performance. The second approach has been and continues to be a mainstay of research on cooking in archaeology. The first approach is a more recent development and highlights a relational point of view. While these two approaches can be intertwined (and in many cases are), moving away from examining cooking tools alone is a productive way to extract more robust social and cultural information about past practices.

Examples of studies that focus on the tools and contexts of cooking and food preparation are abundant, and researchers are interested in answering a plethora of questions. Many studies analyze ceramic cooking pots (Broekmans et al. 2004; Dikomitou-Eliadou et al. 2016; Gauss et al. 2015; Hein et al. 2015; Joyner 2007; Müller et al. 2015; Nelson 2010; Øye 2011; Vokaer 2010; Whitbread 2015; Whitley and Boileau 2015; Winther-Jacobsen 2015), vessels with legs used for cooking (Sophronidou and Tsirtsoni 2007), and cooking stands (Banducci 2015). The size and quantity of cooking vessels may be used to estimate the number of diners (Cheetham 2010). Many consumers could indicate communal consumption or an event, whereas fewer consumers could indicate smaller, quotidian gatherings. Another example is the comparison of tools, food preparation, and cooking facilities in different contexts to learn more about the range of food processing techniques used at a particular place and time (Peyronel and Spreafico 2008). Some archaeologists are examining hearths, stoves, ovens, and furnaces (Papadopoulou and Prévost-Dermarkar 2007; Papaefthymiou et al. 2007; Rova 2014; Wilson and VanDerwarker 2015), including portable, decorated Hellenistic cooking stoves in Egypt, their local copies (Thomas 2014), and earth ovens with rock heating elements (Black and Thoms 2014). Others are looking at evidence for stones or clay balls used to cook food indirectly (Atalay 2005; McCoy 2011; Simms et al. 2013; Thoms 2008) and grinding tools for food preparation (Biskowski and Watson 2013; Ebeling and Rowan 2004; Peyronel and Spreafico 2008).

According to Gokee and Logan (2014), it is impossible to separate food 
production and craft production in everyday life because the tasks, tools, laborers, spaces, fuel, knowledge, social structures, and cultural values are often shared between the different jobs. They also argue, and many authors agree, that both the production of crafts and culinary practices can shape and materialize social distinctions because both require the makers to embody cultural knowledge in order to produce (Arthur 2014; Gokee 2014; Logan and Cruz 2014; Lyons 2014; Stahl 2014). They are not alone in their call for a greater emphasis on comparative analysis. The authors in a book on Mediterranean archaeology edited by Spartaro and Villing (2015) explore culinary practices and craft production together. Although they do not use a "relational" approach to the social actions of craft and cuisine (Stahl 2014), they are still concerned with the crafting of ceramics that are used for culinary practices and what a study of craftwork can tell people about other practices in the past. Villing and Spataro (2015) instead call for a "reflexive" approach following the New Archaeology.

Other archaeologists have begun to study crafting and culinary practices in complementary ways. Roddick and Hastorf (2010) examine food preparation, serving, and pottery production to investigate subtle changes during the Formative period in the southern Titicaca Basin in Bolivia. Comparing the different socially embedded practices, or what they describe as "tradition," they explore the link between tradition and memory, and how memory forms from both nondiscursive and discursive practices (Roddick and Hastorf 2010). Some archaeologists examine the production and use of one class of tools, such as cooking pots, over time to discuss either stability or change to the cuisine in the context of social, economic, or political change (Rotroff 2015). Others investigate the production of particular ceramic vessels within one period of time, along with culinary practices and archaeological contexts, to learn more about regionally shared social practices (Graff 2012).

Researchers have looked for specific ways that cooking and craft production might be socially interrelated. One common thread is that the same people were simultaneously involved in the production of ceramics and the production or preparation of foodstuff. Some authors have pointed out the limitations of archaeological production typologies due to this research. Logan and Cruz (2014) demonstrate that food preparation activities at the 
site of Makala Kataa in Banda, Ghana, from the 18th to the 20th centuries $\mathrm{AD}$, were likely carried out by the same individuals who made pottery, possibly with shared techniques, tools, and gestures. Goldstein and Shimada (2010) examine the relationship between food preparation and craft production in what they described as a "suprahousehold" yet domestic context. They found that the people who were involved in ceramic production were simultaneously involved in corn beer production (Goldstein and Shimada 2010). De León (2009) discusses the complimentary relationship between the production of salt and the production of pottery. $\mathrm{He}$ found that the organization and scale of production did not necessarily fit long-standing production parameters used by archaeologists. The same person or the same small group was likely doing these different but related tasks.

While some researchers question archaeological production typologies when studying food preparation, some are interested in testing the capabilities of these disciplinary stalwarts. Thinking about how cooking itself could be considered a craft specialization, LeCount (2010) examines the idea that Maya palace cooks could be an example of attached specialists. She uses Costin's (1991) production parameters to analyze food preparation data from the Maya site of Xunantunich and finds them effective for identifying variations in elite and nonelite contexts. The parameters also were lacking because they focused on the production of commodities. LeCount argues that thinking about food as a commodity limits archaeological interpretation and obliterates the intersections of socially embedded obligations individuals fulfill in society. Cooking and food preparation as a daily task does not fit under established definitions of specialization but does significantly impact normative social negotiations in many ways (LeCount 2010).

\section{Identities and Culinary Labor}

Archaeologists are interested in who was cooking and preparing food in the past and how an individual's identities played a role in their work. Many categories of social difference play a role in the preparation of food, such as gender identity; age; hierarchical social distinctions such as rank; social, economic, and political power; distinct professions; cultural or ethnic 
affiliation; and religious beliefs. The relationship between an individual's identities and their role in culinary labor highlights theories of practice, agency, and gender.

One category of social difference that archaeologists discuss significantly in culinary research is gender. Many studies, both archaeological and ethnographic, in different parts of the world, point out that food, especially for daily consumption, was largely prepared by women (Bray 2003a; Brumfiel 1991; Crown 2000; Delgado and Ferrer 2011; Dietler and Hayden 2001a; Goody 1994; Hastorf 1991; Jones 2009; Logan and Cruz 2014; Lyons 2014; Montón Subías 2002; Stein 2012). Does this mean that food preparation should always be attributed to women? Although ethnohistoric evidence can help determine who is cooking (e.g., Brumfiel 1991; Crown 2000; Logan and Cruz 2014; Meyers 2008; Pezzarossi et al. 2012; Rodríguez-Alegría and Stoner 2016), sometimes there is nothing to tack onto (Wylie 2002), except the very broad explanation that there is ethnographic evidence women performed this kind of labor. While many believe that women took on the bulk of food preparation activities, there are many examples where men play a significant role in culinary labor (Clarke 2001; Deetz 2015; Deori 2016; Dupont 2015; Jones 2009; O'Conner 2010; Scaramelli and Scaramelli 2012). As pointed out before, it is important to not generalize about women's work (or any activity) in the past using social assumptions from the present (Atalay and Hastorf 2006; Logan and Cruz 2014; Preston-Werner 2008, Robin 2006; Stahl 2005; Montón Subías 2002), something Bolger and Wright (2013) call the "gender trap." Arguments concerning the sexual division of labor are stronger when they are demonstrated in context using more than one type of evidence.

The archaeology of food preparation and cooking continues to demonstrate that archaeologists still need to question gender binary assumptions in discussions about the division of labor. For example, archaeological evidence from many different contexts demonstrates that social roles do not always involve a strict gender binary that is hierarchical. In Mesoamerican prehistory, for example, O'Conner (2010) argues that the cooking practices of the Maya emphasized complementary rather than hierarchical gender roles. Males and females had a specific role and designated location to 
pursue that role, but they needed each other to complete the necessary tasks for society. Other archaeologists also discuss work on foodways related to gender complementarity in the context of Mesoamerican prehistory, but Brumfiel (2013) argues that there is evidence for variability in the ways different genders performed actions, which include gender complementarity, collaboration, and gender fluidity for some tasks. In Fiji, in the South Pacific, Jones (2009) discovered that men were associated with the oven house where special foods were baked for small, regular feasts and large, irregular feasts. Women, on the other hand, were associated with the kitchen and its hearth fire, boiled foods, and everyday meals. While there was a sexual division of labor, each participated in regular food preparation and cooking. Archaeologically it might be difficult, without ethnoarchaeology or other forms of evidence, to distinguish between the two cooking installations and their gender associations. But these associations were very important to the Lauan in Fiji; to conflate them would obfuscate cultural information (Jones 2009). In Greece, at the end of the sixth century and beginning of the fifth century $\mathrm{BC}$, terracotta figurines from Boeotia depicted daily life scenes of both men and women preparing food and cooking (Picazo 2008). However, Tsoukala (2009) argues that terracotta statuettes and vase paintings, from the same period but from Greek cities in southern Italy, Sicily, and Cyprus, mainly represent women processing food, especially cereals, and that these objects reinforced the identity of a female as virtuous, hard working, and directly connected to food preparation. In Greece and Rome, social expectations involving food preparation did not always stem from gender identity, which was sometimes fluid, but from other social aspects of identity, such as being a free person or a slave (Dupont 2015). These varied examples highlight how gendered labor can be teased out from the archaeological evidence and its particular, contextual significance.

A comparative approach that examines the practices involved in different jobs might be able to highlight gendered labor, and one of the jobs examined can be food preparation. Gokee (2014) argues that comparing pottery production and culinary practices in a context where women mainly made and used the cooking pots would help avoid uncritical gender associations. Logan and Cruz (2014) analyze what they describe as "gendered taskscapes," 
in Banda, Ghana- different but related jobs done mostly by women, such as making pottery, agricultural production, and preparing food. The framework of "taskscape" was derived from Ingold (1993). They contend this approach can help illuminate the relationships between technology, gender relations, political economy, and daily life. Lyons (2014) argues for the importance of comparing the work and social contexts of crafts makers (such as potters and smiths), farmers, and cooks to understand the creation of social differences. In her ethnoarchaeological work, Lyons found that women were associated with cooking and the home, while men were associated with farming and the field in Ethiopia. Some women were potters, and while women were linked to pottery more broadly because they used it frequently in cooking, potters were marginalized. This marginalization occurred because potters performed activities that were considered male, or at least nonnormative female, such as picking up a metal hoe and digging in the ground for clay, which created a different ontological category (Lyons 2014). Lyons discusses the necessity to study different aspects of the "culinary continuum" because they are all interrelated and form notions of difference.

Some archaeologists argue that even in positions with relatively little social, economic, or political power, cooks played a crucial and powerful role in social negotiations because of their culinary labors. In colonial Virginia, the cook at the plantation owner's home was an African slave who was trained in a European culinary repertoire. Although the cook was a slave, often a woman, working in an inherently oppressive situation, Deetz (2015) argues that the cook had the ability to negotiate social relationships and benefits with other slaves and with the plantation mistress. This was, in part, because the cook had access to foods that other slaves did not have, but wanted, and the mistress relied heavily on the cook not only for meals at the plantation, but for her reputation as a good hostess (with great food) within the community (Deetz 2015, p. 121). In another example, Joyce and Henderson (2007) argue that women who produced cacao drinks for feasts in ancient Honduras created the possibility to claim credit for their work by saving the final part of the preparation for the guests to see. They would grind seeds into the drink and use other techniques that encouraged foam production in front of the guests creating a "meal-as-event" (Joyce and Henderson 2007, p. 
651) that could also put the cooks and their work in full view. Cooking also may be a bridge between people of different identities, allowing them to negotiate together. Croucher (2011) argued women with different social identities, such as free wives and concubines, coming from a range of different African communities and from Oman, probably all cooked together in the Omani colonial households in east Africa in the 19th century. Cooking and food preparation in this case may have been one way for individual women to negotiate their positions in the colonial household (Croucher 2011, p. 77).

Creating distinctive dishes with unique ingredients and specialized equipment was one of the ways Goody (1994) identified "haute cuisine," and archaeologists continue to use his categories to discuss the formation and enforcement of social hierarchies. There are examples of elites differentiating themselves through elaborate cuisine in Mycenaean Greece at the Palace of Knossos (Isaakidou 2007) and the Palace of Nestor (Hruby 2008, 2011). Social hierarchies also were visible in food preparation evidence from Laconia (Langridge-Noti 2015).

Learning how to cook or prepare specific foods, especially those regarded as locally or culturally important, is part of the socialization of cooks and could result in the cooks' access to or denial of social power. Pueblo girls were required to learn how to cook piki bread to become a full-fledged member of their community and probably to become eligible for marriage (Crown 2000; see also Mills 2008). In West Africa, Herbich and Dietler (2008, p. 233) describe how a new Luo wife had to be resocialized by her marital family, such as learning specific recipes for her husband's homestead. She was not allowed to cook in her own home for some time until her senior mother-inlaw decided she was ready, and then she would still need to compete with any other co-wives within her husband's homestead. Deetz (2015, p. 125) details how James Hemings, Thomas Jefferson's head cook at Monticello, traveled to Paris in 1784 to be trained in French cuisine. While this example is unique, it does demonstrate the desire for cooks with specific kinds of knowledge. Excellent cooks were highly valued on the Virginia plantations and were trained and subsequently promoted within the kitchen based on their skills alone (Deetz 2015). Culinary mastery also was highly valued 
during the Western Han period in China. Excavations of the Marquise of Dai family burials, dating from $168 \mathrm{BC}$, revealed prepared dishes with labels written on wooden sheets that identified each dish by how it was cooked and seasoned (Sabban 2015, p. 399). A text discussing the culinary practices of the time explains how every social class was interested in delightful cuisine that required professional cooks (p. 399). In addition, a professional kitchen is depicted engraved on a stone from a tomb, revealing the complex culinary division of labor at that time (Sabban 2015, p. 400). The knowledge required for the preparation of food that is appropriate and in accordance with particular social rules also points to the significance of the learning process (Morrison 2012).

The setting where food preparation takes place also is a consideration for the identity of the cook, their work, and the subsequent stages of consumption. If the food was prepared in a more secluded area, then it could be intended for a smaller group requiring more privacy, while cooking in a larger more open area could mean the meals were prepared communally or for a larger community purpose (Atalay and Hastorf 2006; Hegmon et al. 2000; Pollock 2012; VanDerwarker and Detwiler 2002). Cultural and religious views on work and space also may play a role. Lewis (2007) found a change in the cooking and food preparation practices of the people in Yemen from the prehistoric to the early historic period. Prehistoric living spaces were designed for community living. Cooking was done out in the open, and the cooking pots were designed to feed many people. In the early historic period, the living arrangements changed to create more private, fortified living spaces where cooking took place indoors. At the 19th century site of Mgoli in East Africa, Croucher (2011) found evidence of a public section in the front of the house where men entertained and a private, female section in the back of the house where cooking took place. Merchant houses in Mocha, Yemen, during the first half of the 18th century also had distinguishable spaces that served public and private purposes (Um 2003). There was a public space on the ground floor where transactions took place and where there was access to the merchandise, and a private section on the upper floors of the house, including the roof, where women cooked. These examples demonstrate how context is essential for understanding identities 
and culinary labor.

\section{Social Boundaries, Culture Contact, and Colonialism}

Recent research uses cooking and food preparation to understand how societies or social groups define themselves and how others might define those groups in turn. Instead of relying on material culture alone as a proxy for social groups, a focus on cooking and food preparation tends toward a practice theory approach, with a reconstruction of the food preparation and cooking chaîne opératiore, food preferences, and cooking tools to indicate social boundaries and change. Culture contact in the context of food is discussed by Twiss (2012a) and, specifically for the Andes, by Cuellar (2013). Social boundaries and the negotiations of those boundaries are a significant theme in the literature on cooking and food preparation. Much recent work focuses on the importance of cooking in the negotiations of unequal social relationships. This is especially true within the context of colonialism where power is asymmetrical. The examination of cooking in colonial contexts is a productive framework for exploring key questions about social and political negotiations, mobilization of labor, resistance, and identity construction and maintenance.

The literature on cooking and food practices in colonial contexts concerns whether or not there was a change in culinary practice during the process of colonization (such as a creolization), whose dishes were preferred and why, and how they were prepared. These questions emerge as archaeologists seek ways to understand the everyday realities, unwritten policies, and nuances of colonial situations. In an early influential work, Deagan (1974), argues that marriages between Native American women and Spanish colonial men resulted in a process of acculturation. This was reflected in the material culture in the homes, where ceramics used for consumption in the maleoriented public sphere were European, and those used for utilitarian purposes in the kitchen were local, native, and associated with women. Deagan's explanation is known as the "St. Augustine model," and while it has been very influential it has recently been critiqued (Cuellar 2013; RodríguezAlegría 2005; Voss 2008).

Changes in cooking and food preparation over the course of the colonial 
period were not simple acts of acculturation, but instead were fluid and negotiated. In some cases, Indigenous cuisines were maintained (Briggs 2015; Schucany 2005), while the Indigenous people selectively chose to incorporate either new foods over time (Dietler 2010a; Mills 2008; Reddy 2015) or new technologies and/or tools (Scaramelli and Scaramelli 2012) for food preparation. In many cases, cooking pots were more conservatively maintained over time (Dietler 2010a; Rotroff 2015; Schucany 2005); in others, the choice of where to purchase cooking pots was affected by diminished political control over the local economy (Rodríguez-Alegría and Stoner 2016).

Colonial powers have used culinary practices to make colonial situations more tractable for themselves. Dawdy (2010) argued that in French Louisiana in the 18 th century, the French colonists actively transformed local, unknown (to them) Native American food resources into a known French cuisine using French culinary practices. The French considered this "an emblem of colonial accomplishment" (Dawdy 2010, p. 402). Although most of the colonists had African slaves who prepared their food, aspects of African cuisine were absent from the colonial writers' accounts. Foods common in African cuisine were found archaeologically but were excluded from the colonial descriptions. According to Dawdy (2010, p. 408), the French colonists portrayed themselves as actively incorporating and transforming Native America into the colonial French project, but Africans were simply considered labor and not a part of the process.

Despite the context of slavery in the United States, cooks showed resilience to adapt to the circumstances and also maintain aspects of their culture through cooking and serving. African slaves assigned to plantations in the British colony of Virginia shared a large cooking pot to cook communal meals resembling traditional West African stews (Deetz 2015, p. 120). Enslaved cooks, bought or inherited by the plantation owners to cook for their family, not only learned how to cook European style dishes but also incorporated aspects of African cuisine. Okra was used to thicken stews (a technique borrowed from West Africa) instead of flour (a technique from French cuisine) (Deetz 2015, p. 122). 
There are other examples in colonial contexts where different groups made active choices in their situations through food and cooking, what Dietler (2010b) calls "selective choices" by both the native people and the colonists at different archaeological sites in France. The Gauls chose to incorporate certain nonnative elements but not others, such as the gradual incorporation of wine into the regular diet, the eventual production of wine in Massalia, the rejection of new cooking wares, but the adoption of foreign serving wares. Greek colonists rejected the locally produced serving wares but early on adopted the local cooking wares. Over time the local cooking wares were replaced with Greek wares in colonial Greek homes. Dietler (2010a) cautiously explains that this change with Greek colonial cooking equipment was the result of indigenous women cooking in the colonial homes during the initial colonization period, and gradually Greek women took over the cooking from the Gauls.

Mills (2008) argued women, as the main makers and arbiters of cuisine, were the agents of both stasis and change. Zuni pueblo women were the conduits of cultural transmissions through cuisines during the colonial period (Mills 2008). Cooking reflected women's different encounters and their varied choices in constructing their identities and their family's identities. In similar fashion, despite hierarchical social boundaries, a blending of European, African, and Amerindian groups took place in Brazil, which is reflected in household food processing and cooking done by women (Symanski and Gomes 2015).

In some instances, cooking and food preparation did not change during colonization. Under Inka domination, the Wanka of ancient Peru were forced to perform more work, especially the women, and power was pushed toward the men (Costin 2016). However, food preparation and cooking techniques did not change (Costin 2016, p. 135). Although women were still responsible for food preparation and cooking; their new responsibilities did not change their culinary habits. In Iron Age Mediterranean France, temporal changes in cuisine happened mainly in the urban areas, whereas the more rural regions that were under the Roman Empire did not change their cuisines (Luley 2014). 
The literature on colonial encounters demonstrates that cooking and food preparation do not easily equate to acculturation. The changes that occurred in cooking and food preparation practices over the course of the colonial period in different locations were fluid and negotiated.

\section{Crossing Boundaries and Constructing Community}

Historical accounts that describe the relationships between different regions focus on the dominant power and its greatness. Usually the authors of the historical documents represent the ideology of the political power while the "Other" region is distinguished as different and in some cases barbaric. Archaeological evidence, however, can reveal elements of the relationships between regions that are not visible in the textual evidence. Archaeological studies that examine food preparation identify multiple examples of more nuanced relationships between regions, sometimes including the active construction of new, interregional communities.

Although characterizing foreign submission to the state was an important aspect of legitimate authority in texts, archaeological examples of culinary practice demonstrate variation in this view. Despite ancient Egyptian imperialism and its strict separation from non-Egyptian communities, evidence from the southern Egyptian frontier location of Nubia indicates that Egyptians and Nubians worked together, possibly intermarried, and forged social, political, and economic ties (Smith 2003). The practice of the people on the ground, discovered through archaeological evidence of cooking and serving, differed from the written, ideological accounts (Smith 2003). Using food preparation techniques such as butchering practices, and tools such as indigenous cooking pots, Stein (2012) argues that the local Anatolian women living at Hacinebi in Turkey between 3700 and 3100 BC intermarried with the male Mesopotamian colonists and traders who were living in their city. This helped build alliances with the powerful local families, making it easier for the Mesopotamian colonists to establish a more permanent presence.

Some studies articulate how certain foods, and the ways they were prepared, or certain food preparation tools, act as a unifying element in society. This is visible archaeologically in what the society considered staple foods. Delgado 
and Ferrer (2011, p. 190) contend that the daily physical act of transforming raw cereals into Phoenician food, such as grinding grain to prepare bread, was ubiquitous and traversed social boundaries. Sharing the same food preparation practices in different locations also could produce similar memories of sounds as well as tastes and a shared sense of identity (Delgado and Ferrer 2011, p. 190). Philistine immigrants to Canaan in the Iron Age brought with them smaller cooking vessels that worked well for their cuisine and small nuclear families (Ben-Schlomo et al. 2008). The local communities (some Israelites) had cooked larger meals of soups in open cooking pots but over time changed to smaller meals cooked in Philistinestyle cooking jugs. The researchers argued that the local community adopted the Philistine cooking techniques, indicating that the Philistines influenced their neighbors and forged some community ties. This argument countered the biblical portrayal of the Philistines as the enemy of the Israelites (BenShlomo et al. 2008, p. 112). During 19th century immigration to the United States, interethnic community relationships were forged over the exchange of both food and food preparation tools. Archaeological evidence from a mining town in California, with Chinese and Native American Paiute neighborhoods, reveals that the two neighborhoods shared foods and tools (Sunseri 2015, pp. 426-427). The Chinese immigrants and the Paiutes were discriminated against and marginalized by the European Americans in this mining frontier, yet they managed to resist some persecution by having their own ethnic neighborhoods where they prepared their own foods and shared food and tools with their similarly excluded neighbors (Sunseri 2015).

\section{Cooking and Ritual}

Another theme in recent studies is cooking in the context of ritual. Ritual is most often associated archaeologically with sacred and mortuary sites; it is often conflated with religious practice, but there also are domestic and secular rituals (Rowan 2011), as well as ritualized regular practice (Hayden 2014; Russell 2015). Theorists who study ritual recognize the problems with the sacred and profane dichotomy and its associated complications (e.g., Rowan 2011; Swenson 2015). Archaeologists who analyze cooking and food preparation are poised to contribute to the discussion. 
One way archaeological research on food preparation contributes to theorizing about ritual is by taking on a theoretically feminist perspective that does not assume Manichean spheres of activities. One example is Heitman (2016), who uses legacy sources to reconstruct archaeological data on tools for grinding corn that were collected in Chaco Canyon, New Mexico, in the early 1900s. These tools were recorded and sometimes collected, but largely dismissed by archaeologists at the time. Heitman highlights aspects of Chacoan women's work that blurred the lines between daily task and sacred practice. She combines the work of Fowles (2013) and Mobley-Tanaka (1997), along with legacy data from the Chaco Research Archive, to demonstrate that women's food preparation labor, specifically grinding corn using manos and metates, in specific work spaces, was deeply embedded in both religious practice and daily practice. Heitman's work demonstrates the complexities of ritual in Chacoan society using the labor of food preparation and a feminist lens that allows her to step out of the proverbial box of labor, ritual, and power assumptions.

Cooking and food preparation in the context of ritual often involves feasting, which is frequently associated with mediating relations of power and resistance. Different foods or different treatment of ubiquitous foods in each context can indicate a special meal. For example, evidence from Durrington Walls, part of the Stonehenge complex and believed to be the village where the builders of Stonehenge lived, reveals not only feasting in both large and small scale, but that food for public ritual was prepared differently than food in the village homes (Craig et al. 2015). The area called the Southern Circle, believed to be a public hall, contains ceramic vessels that were used to prepare dairy products. Most of the vessels excavated from middens near houses were used to cook pork and dairy products were not found. The archaeologists argue that the preparation of dairy products was part of a public ritual at this site. In another example, from the Middle Formative to the Late Formative period in the Titicaca area of Bolivia, special foods, such as higher-quality fish and the introduction of maize, were used in ceremonies, indicating that distinctive foods were part of ritual feasting (Hastorf 2012b). At Guijarral in northwestern Belize, a Late Classic Maya settlement, Goldstein and Hageman (2010) compare daily food production at 
a residence with feasting food production at an ancestral shrine, finding that certain foods were specially selected for feasting and demonstrating what they call "coded food use" (p. 422) for ritual purposes.

The manner of preparing and cooking meat is another way archaeologists access ritual activity. Animals were valued in many societies, and in some cases that sense of value was mediated by ritual prescriptions for preparing food. How the animal was butchered; if the bones were burned and how much; selective inclusion of certain parts of an animal, species of animal, or age of animal; or if the bones were modified in any way can help identify the actions, choices, and preparations that took place (Aranda-Jiménez and Montón-Subías 2011; Gifford-Gonzalez 2008; Halstead and Isaakidou 2011; Isaakidou 2007). Coupling the evidence for treatment of animal bones, associated artifacts, and contextual evidence helps archaeologists identify ritual aspects of food preparation. Greenfield and Bouchnick (2011) use Jewish dietary laws (Kashrut) and butchery laws (Shechita) to identify Jewish butchering practices and culinary choices in zooarchaeological data from the Second Temple Period city dump of Jerusalem, other sites from the Late Second Temple period, and sites where non-Jews lived. The presence of animals considered kosher by Jewish religious law, and Jewish butchery practices, can be significant indicators of Jewish identity (Greenfield and Bouchnick 2011). In a similar study of butchering practices at two 14th century sites with observant Jewish populations in Andalusia (Spain), the presence of only kosher animals, and the regulated butchering practices, positively identifies the locations of the Jewish communities and their ritual activity (Valenzuela-Lamas et. al. 2014). At Nopigeia-Drapanias, a Bronze Age site on Crete, Hamilakis and Harris (2011) identified an event as ritual because only a select range and age of animal species were butchered, and these preferred animals were cooked with specialized equipment. The tripod cooking pots, saddle querns, and drinking cups they found indicate that the food preparation equipment along with the remnants of consumption were purposefully buried and likely part of a ritual act (Hamilakis and Harris 2011, p. 214). At Çatalhöyük, Russell and Martin (2012) describe daily meals prepared in the home that consisted of stewed or baked meat of sheep and goat. Feasts include wild animals, such as cattle, that are cooked 
similarly to daily meals. Evidence for bone grease processing was found in both feasting and domestic contexts.

Food and drink often were prepared for the gods in ritual contexts. In the Near East more broadly, baked bread and cakes were a common offering to the gods (Delgado and Ferrer 2011; Restelli and Mori 2014; Sallaberger 2012; Samuel 2013). Iconography and texts for Syro-Palestine of the first millennium BC indicate that foods made from cereals, such as wheat and barley, were a significant part of the ritual offerings to the deities (Delgado and Ferrer 2011). Meat also was a common offering in many places, though distinctions archaeologically between sacred and secular are debated (for a discussion on zooarchaeological evidence for ritual practice in the Old World see Ekroth and Wallensten 2013). In Assyria and Anatolia, the deity receiving the meat dictated how the meat should be cooked (Gaspa 2012). At the 13th century BC city of Emar in Syria, animal sacrifice happened only on specific festival days during the year, so the mere presence of meat identified a difference between daily meals and ritual food offerings (Sallaberger 2012). Blood sacrifice and the ritual butchering and cooking of animals was an element in the Greek civil religion for centuries (Detienne 1989; Ekroth 2007). Animal sacrifice and its associated butchery also was an element of Hittite religious practice in Anatolia (Popkin 2013).

Sometimes food for the divine was prepared in the home. In the Levant, women often prepared food offerings for temples and shrines in their homes (Ackerman 2008, pp. 144-146; Delgado and Ferrer 2011, p. 197). At Emar in Syria, food for the temple was prepared in private homes and sometimes in secondary buildings associated with temples (Sallaberger 2012).

In other cases, food was prepared closer to a sacred space. Installations for cooking and preparing food were extant in temple complexes in Ur III Mesopotamia (Allred 2006), Babylonia, and Assyria (Sallaberger 2012). There is evidence that food was cooked within Phoenician temples and shrines (Delgado and Ferrer 2011, p. 198). In Cyprus, baking molds found near the Phoenician temple of the goddess Astarte depict the goddess herself with arms outstretched. These baking molds were used to bake breads or cakes as offerings to the goddess (Delgado and Ferrer 2011). In pueblos in 
the northern part of the southwestern United States, food preparation rooms were linked to kivas - spaces connected to religious practices (Heitman 2016).

Food and drink also were prepared for the dead and in their honor. At the Wari site of Conchopata in Peru, a brewer woman and some of her children were ritually buried, and in the process, her family slaughtered and cooked a llama to seal the home (Isbell and Groleau 2010). In northeastern Argentina, at the El Dorado mound (part of the Taquara/Itararé tradition), Iriarte et al. (2008) found evidence of several generations cooking meat at the burial site of their dead leader. Earth ovens lined with stones were used to steam meat slowly for hours and then consumed along with a fermented maize beverage in honor of the chief (Iriarte et al. 2008). Also in South America, the Moche prepared funerary feasts near two cemeteries at the site of El Brujo

(Gumerman 2010). Evidence for the practice of kispu, the Akkadian term for "funerary offerings" and commonly associated with feeding the dead (Tsukimoto 2010), is found at the Middle Bronze Age city of Qatna in Syria (Pfälzner 2007, 2012) and at other sites in the Near East (Pfälzner et al. 2012). Similarly, during the first millennium BC, in the Iron Age of SyroPalestine, members of the community offered a variety of food and drink to their ancestors in tombs (Delgado and Ferrer 2011). The Old Kingdom tombs from the Memphite necropolis in Egypt have butchery scenes and scenes of food cooking in pots (Ikram 1995). In the tombs of high officials, wild game is often depicted in funerary scenes; animals are methodically butchered and grilled over braziers on a skewer for funerary feasts (Ikram 1995; Tallet 2015).

A final point on ritual concerns taboos. Food and cooking taboos are well known, especially in the context of religious practices and sociocultural rules. They are less known archaeologically (see Fowles 2008; Twiss 2012a) but do emerge in research on anthropophagy. While the taboo of eating human flesh by other humans may be our own, most instances of anthropophagy were ritual in nature.

A full consideration of changing perspectives on cannibalism is beyond the scope of this review (see Lindenbaum 2004; see also Walker 2001 for a 
bioarchaeological perspective). What is relevant to this review is the evidence for processing of human meat for consumption. Evidence for the practice of anthropophagy exists for the Puebloan southwestern United States, but not exactly in the way that some archaeologists have argued (see McGuire and Van Dyke 2008; Nichols and Crown 2008). One way archaeologists identify anthropophagy is by studying the processing and cooking of human osteological remains. Novak and Kollmann (2000) analyzed human remains from the Fremont culture area in south-central Utah, dating to around AD 1000, and found that human bones were processed and cooked just like animal meat for consumption. Evidence for capturing, killing, and processing human bodies at the Sacred Ridge settlement in the early AD 800s comes from a combined analysis of the butchering patterns on the bones, human remains on a metate, and a cooking jar that contained human myoglobin (Kuckelman 2016). Using multiple lines of evidence including osteological, taphonomic, and stable isotopic, Jones et al. (2012) found evidence for human consumption in the Lau Group, Fiji, which they interpret to indicate a variety of ritual practices involving anthropophagy. A different picture emerged in a study of Neolithic human remains from Scaloria Cave in southern Italy that were systematically defleshed, cut, and scraped as part of burial ritual and not cooking (Robb et al. 2015). Similarly, Pérez et al. (2008) analyzed human bone processing, including ethnohistoric information, to demonstrate ancestor workshop and ritualized annihilation of enemies at La Quemada, Mexico, between AD 500 and 900 .

Investigations of survivor cannibalism (eating human flesh for survival purposes) also rely on evidence for the processing of human remains. Research has been conducted at different sites in the Sierra Nevada known collectively as the Donner Party camps (Dixon et al. 2014), where the infamous pioneers were caught in an unexpected bad winter storm on their way west in AD 1846. They starved because of a lack of food, and famously were said to have cannibalized each other to survive. Excavating the site and analyzing the remains, Dixon et al. (2010) found extensive processing of animal bones, patterns that fit with instances of starvation (Novak 2014), but were unable to conclude that the party had resorted to cannibalism. 


\section{Politics and Economics}

Cooks and their culinary activities play a role in the political and economic spheres. Most discussions about politics and economics in the past focus on polities, elites, and elite-sponsored events. High cuisine, for example, has been used to identify social hierarchies (after Goody 1994). Cooking and food processing in buildings associated with political authority or at a large scale are interpreted as serving a political function. Cooking also must take place in politically charged contexts, such as within military camps, where the relationships between the military-backed polity and the people are articulated (discussed further below). The connections between rituals, especially in the context of feasting, and politics have been discussed (see Dietler 2001; Twiss 2012a). But finding political and economic action archaeologically through the study of cooking is one way that domestic, daily work is becoming a more significant research topic. As a complex social activity, cooking regularly involves different relationships and actions to get the job done, all of which require a combination of economic knowledge and political savoir faire, especially within the home (de Certeau et al. 1998; Douglas 1997). Finally, the cross-pollination between the home and the larger society is an important consideration (Gokee 2014; Lyons 2007). The connections between power structures and the populace that lives and works within the purview of said power are an important theoretical issue that can be addressed by cross-examining different types and contexts of food preparation (e.g., Bray 2003a; Hastorf 2012b). The study of cooking can illustrate politics and economics at both the state and domestic level.

Culinary preparation can illustrate political hierarchy and social differences. Distinctive, elite cooking took place at Bronze Age Knossos (Isaakidou 2007) and Pylos (Hruby 2008). Cooking highlighted class differences among the Inka during feasts (Bray 2003b, p. 20), the Maya (Goldstein and Hageman 2010), and people in the Titicaca area during the Formative period (Hastorf 2012b). Food preparation identified social status in historic period Laconia (Langridge-Noti 2015). Although much earlier in time, according to Wright (2014), the emergence of an unequal distribution of food preparation facilities at Neolithic Çatalhöyük demonstrated a transition away from egalitarian organization. In addition, the more "private" instances of 
jockeying for power within elite contexts are visible in the cuisines of great palaces such as at Dahomey (Monroe and Janzen 2014) or great houses in Mgoli in East Africa (Croucher 2011).

The recent literature explores the influence of women on politics and economics from working daily in their homes. Agame women in highland Ethiopia were active in shaping politics and cultural identities through routine, gendered practices such as cooking and making cooking tools (Lyons 2007). Lyons (2007) argues that the activities of making cooking griddles to roast the grains for thollo (a unique dish made only by Agame women) and making the thollo itself were material practices that indicated political and cultural identity to all Tigrayans and that the traces of these practices could be found archaeologically. Similarly, women in Upper Senegal during the second millennium AD took part in local and regional political economies through their ceramic production, food preparation, storage, and serving of food in ceramic containers (Gokee 2014). The techniques of production and use of pottery containers in cooking was one way that women negotiated their gender, cultural identity, and involvement in the political economy. Research focused on colonial encounters that use cooking and food preparation to access social information also discusses the role of cooks, often women, in sociopolitical and economic negotiations (Deetz 2015; Rothschild 2015; Smith 2003).

Archaeologists also can identify the marking of social difference by examining dissimilar ways of butchering and preparing meat. According to Detienne (1989), for centuries Greeks used the ritual killing and cooking of animals to exercise political power, mark social difference, and differentiate between Greeks and non-Greeks. The archaeological evidence for these events is currently examined through zooarchaeological studies (Ekroth 2007; Ekroth and Wallensten 2013). In South Asia, Chase (2012) looked at butchery practices at Gola Dhoro in Gujarat ca. 2600-1900 BC and found that people inside the walled area prepared their meat differently than those who lived outside the walls. He argued that while the initial butchering was the same inside and the outside the enclosure, there were differences related to food preparation and cooking due to differential social status. 
Recent work on food preparation challenges established ideas concerning food prepared and distributed by the state. In ancient Mesopotamia, centralized institutions provided food to the gods, to the ruling elites and their families, to workers attached to the palace, and food rations to those hired or conscripted for projects. Archaeological, iconographic, and textual evidence for palace and temple kitchens that fed the gods, the elite, and many other workers in Mesopotamia substantiates this view (Allred 2006; Bottéro 2004; Van De Mieroop 1999). However, this model does not fit every site or every chronological period in the Near East. In Syria during the third millennium BC, Rova (2014) found evidence that bread was not massproduced in a central location by the state; instead, bread was baked in homes and communally by the populace at Tell Beydar, and different production sectors of the public complex (a temple or a building with a ceremonial function) each had their own bread ovens. Rova (2014) interprets this to mean that primary food production was decentralized, especially since the provided rations were usually grain. In Egypt, Samuel (2013) found that individual households at Amarna in Egypt had ovens and baked their own bread; at the same time he interprets large numbers of temple rooms with ovens as evidence that the state supplied a large quantity of bread to the workers. These findings are significant because so many discussions about political institutions have the Mesopotamian model as the classical model (Kenoyer 2000).

Whether cooking activities, or the cooks themselves, are seen or unseen can change the social value placed on the acts of cooking itself. Joyce and Henderson (2007) argue that producers of cacao drinks for feasts, probably women, created the opportunity to claim credit for their work by saving the final part of the preparation for the guests to see. Portable cooking tools, such as ovens or braziers, also may indicate greater visibility for cooks. Hellenistic examples of braziers were found in house contexts, probably on roofs or in courtyards (Thomas 2014). Thinking about "being seen" in a different way, Isaakidou (2007, pp. 10-11) describes how iconography of the Late Bronze Age on Crete depicts diners who were distinguished from those serving food by the clothing they wore; diners wore long garments that covered their bodies whereas those serving food wore more revealing, short 
garments.

Some archaeologists work on the production, exchange, and consumption of cooking pots to learn more about politics and economics, finding that political change affected cooking pot exchange and consumption in surprising ways. From the Aztec period to the colonial period at Xaltocan, the market exchange of cooking pots was affected by political changes, even though political goals were not explicitly concerned with the domestic economy (Rodríguez-Alegría and Stoner 2016). In northwestern Syria at the end of the third millennium $\mathrm{BC}$, even though the production, distribution, and consumption of a specific type of cooking pot was not controlled by the state, the consumption of the pots might have been connected to a politically charged regional ritual (Graff 2012). In the Athenian Agora from the early Iron Age to the Hellenistic period, one island, Aegina, produced very popular cooking pots that were imported to Athens and all but replaced local cooking pots in the late sixth and fifth centuries BC (Gauss et al. 2015; Rotroff 2015, p. 202). Athens defeated the island of Aegina and in $431 \mathrm{BC}$ forcibly removed the Aeginetan population and installed a klerouchy (a type of colony established by Athens where Athenian settlers would retain their citizenship; the colony was politically dependent on Athens) on Aegina (Rotroff 2015, p. 203). Rotroff (2015) expected to see Aeginaten pottery disappear from the Agora after $431 \mathrm{BC}$, but instead the quantity of Aeginaten pottery increased until the end of the fifth century. She argues that the archaeological data reveal a lag time between the historical events and changes in cooking pots. The political effects on ceramic production, exchange, and consumption should be demonstrated, as in the Aegina example, and not just assumed.

Provisioning of the military provides another way to examine politics and economics. Fales and Rigo (2014) compare illustrations of temporary Assyrian war encampments and texts that describe the military groups and the kinds of provisions they received. Food was prepared by noncombatant specialists that included native Assyrians and non-Assyrians. For Assyrians, meals were cooked by specialists and eaten in individual tents with servants attending. Non-Assyrians cooked for themselves and were watched by Assyrian guards (Fales and Rigo 2014, p. 425). Based on these data, the 
Assyrian army did not organize large, centralized dining facilities. I would argue that this indicates the army was wealthy, unencumbered by war, and well accommodated by their state. In another example, ordinary Roman soldiers on the frontier prepared and consumed food within their small social units of eight men in a small physical space that contained a hearth, and solders were given metal cooking pots (Carroll 2005, p. 366). There was no central kitchen or specialist cooks for the ordinary Roman soldiers. Only the milling of grain and baking of bread was done in a centralized fashion in a different location within the fort. One thing that is unclear is whether or not female family members also were involved in cooking for the soldiers (Allison and Sterry 2012). Cooking for officers was a different story, involving specialists, luxury foods, and rituals to display rank (Carroll 2005). Carroll's research demonstrates the ways the Roman military used the preparation and consumption of food to establish both social distinction and social integration.

Another study focused on food and its preparation demonstrates discrepancies between historical documents and archaeological data on war encampments. Simmons (2012) studied the British military camps that were occupied during the Waikato campaign of the New Zealand Wars. These wars were campaigns against North Island Maori in New Zealand between 1863 and 1864. Comparing archaeological excavation data of the camps, personal accounts from the soldiers related to food, and official reports such as those prepared for the War Office, Simmons found discrepancies between datasets and very little archaeological evidence for cooking. She found cast iron pots and frying pans but no cooking installations. Many bottles of sauces were used to flavor foods (such as Lea and Perrins Worcestershire sauce), but they are not mentioned in the historical records. These foodrelated data have much potential to answer questions about political and economic activities during the colonial period.

\section{Conclusions and a View Forward}

There are rich current data on the preparation of food. More information than ever before is being extracted from the archaeological remains of cooking and food preparation. The goals are clearly to understand foodways in the 
past, but a new interest in cooking and food preparation and how these data can elucidate social practices, social identities, socially produced relations of power, and social change marks a shift in archaeological thinking. How can this new way of thinking about cooking and food preparation in the past move archaeological research forward?

First, researchers should look for ways to explain uncommon patterns that might reveal social and cultural choices and preferences. Archaeologists comment on the lack of studies concerning food taboos (Fowles 2008; Twiss 2012a), and I also encourage research on this topic. Promising work on Jewish cooking practices in the archaeological record might begin this conversation (Greenfield and Bouchnick 2011; Valenzuela-Lamas et al. 2014). The study of cooking and food preparation in different contexts, with careful attention to the choices made based on the food available, extant residues left behind, cut marks on bones, the parts of the animal used, the lack of animal products or conversely the lack of botanical remains, the different practices (especially compared to similar or related practices), and the different equipment used will make it possible to think about traces of taboos left behind. Researching taboos in cooking would add to knowledge of religious practices and sociocultural-based food preferences (Smith 2006).

Another productive way forward will be to continue Brumfiel's comparative historical analysis, or what others have termed a relational approach. Many of the works discussed above do just this in many substantial and creative ways. The linking of craft production research with investigations into cooking has shown great promise. Studying the work that intersects with cooking highlights aspects of the job that might not otherwise be visible, such as timing, shared tools, or shared gestures. Archaeologists with different subspecializations should continue to work together to facilitate this type of analysis and publish their findings jointly. Comparative historical analysis also will facilitate and enhance research on identity and difference in the contexts of food preparation. Thinking about categories of identity in archaeological research should always be intersectional and reflexive. In other words, archaeological approaches that take identity, such as gender, into account also should consider other identity categories as much as possible, such as race, class, age, ability, and sexual identity. Individuals 
have many identities and the intersection of identities affects the individual's social experience (Crenshaw 1991).

Humanizing the past is another productive step forward for archaeologists who study food preparation and research past experiences. Most recent research on cookery does not discuss memory or the senses, something that should be investigated in the future. We perceive food through our senses, which can create strong associations and memories (Holtzman 2006). Cooking provokes the senses, from the perspective of the cook, their helpers, those who are nearby during the cooking process, and those who will partake in the meal. Just think about the eye stinging effect of chopping onions, sweating over a hot stove, timing in a busy restaurant kitchen, how shelling many freshly picked walnuts can stain the skin on your hands, or the smell of something delicious baking in the oven. The senses, according to Hamilakis (2013), produce affectivity; in other words, they connect people, evoke emotions and memories, and help new ideas emerge. Archaeologists would be remiss to avoid these considerations because they are part of what people experienced and how they lived. Similarly, archaeologists who examine the archaeology of human experience argue that people's experiences are amenable to archaeological investigation (Hegmon 2016a). Examining human experiences can allow the voices of marginalized groups to be heard, such as indigenous people, women, and children, which is a concern of many archaeologists who study cooking. Research into human experiences helps connect the public to archaeological work and demonstrates its importance and relevance. Finally, studying the deep history of human experience also can influence contemporary policies and decision making (Hegmon 2016b). Many archaeologists work on issues that are relevant to contemporary, foodrelated problems such as food security (Logan 2016; VanDerwarker and Wilson 2015), conflict over irrigation projects (Morrison 2010), accumulated changes in land use (Morrison 2016), hunger (Pollock 2012), and climate change (Gaillard et al. 2015). We must continue moving these efforts forward and help create positive changes, not just in the discipline but in our contemporary world.

Despite impressive work on food and cooking to date, the theoretical model building in archaeological studies on cooking and food preparation is 
stagnant. This needs rectification. Researchers are focused on developing new methods for collecting elusive data, and this is crucial for expanding the possibilities of research in archaeology. Archaeologists also are paying careful attention to sound archaeological practice for data collection and detailed data analysis. The wealth of information we are collecting is inspiring. But once the data are collected, they do not speak for themselves. I argue an intersectional approach might be a place to begin building models because it asks us to take different social, political, religious, and economic identities into account when we consider the available data. Not accepting "traditional" (i.e., Western and composed of modern-day concerns) ways of viewing material culture remains, their value in society, and the social relations they produce and reify will help us learn more about people's lived experiences in the past (Gero 2015).

Overall, the future is bright for the study of cooking and food preparation. Evidence for food preparation in the past is becoming more available as archaeologists continue to develop new methods for analysis. With more archaeologists thinking about how a focus on food preparation and cooking can provide answers to many questions about people in the past; continued use of databases to store, share, and search data; attention to collaborative and interdisciplinary research; new technologies to collect data; and the development of new techniques for analyzing data, it is becoming more possible to reconstruct ancient food preparation techniques in context. Adding model building to this list will help us explain and make sense of these impressive collections of data. Expanding our questions beyond those we have always asked, listening to new questions from our students and colleagues around the world, and having an open dialog also will help us bridge gaps in our current models. I look forward to seeing an expanding study of cooking and food preparation in the near future. AQ4

\section{Acknowledgments}

I have deep appreciation and gratitude for the guidance and patience of Gary M. Feinman and Linda Nicholas. They are professional yet benevolent, and this article benefitted greatly from their attention to detail. I also thank five 
anonymous reviewers who provided invaluable feedback that helped me to bring this article to completion. Laura Popova read a draft of this article and provided feedback and encouragement. Finally, my daughter patiently read novels on many nights and weekends when her mama was unavailable, and I thank her for her understanding.

\section{References Cited}

Ackerman, S. (2008). Household religion, family religion, and women's religion in ancient Israel. In Bodel, J. P., and Olyan, S. (eds.), Household and Family Religion in Antiquity, Blackwell, Malden, MD, pp. 127-158.

Alderfer, K. (2016). Taste ancient ales with dogfish head at the Penn Museum. Philadelphia, April 4, Philadelphia, PA.

Allison, P. M., and Sterry, M. (2012). "Family" meals? Who ate where, and with whom, in early imperial military bases? Paper presented at the 22nd International Limes, Roman Frontiers, Congress, Ruse, Bulgaria.

Allred, L. (2006). Cooks and Kitchens: Centralized Food Production in Late Third Millennium Southern Mesopotamia, Ph.D. dissertation, Department of Near Eastern Studies, Johns Hopkins University, Baltimore, MD.

Aranda-Jiménez, G., and Montón-Subias, S. (2011). Feasting death: Funerary rituals in the Bronze Age societies of south-eastern Iberia. In Aranda-Jiménez, G., Montón-Subías, S., and Sánchez-Romero, M. (eds.), Guess Who's Coming To Dinner: Feasting Rituals in the Prehistoric Societies of Europe and the Near East, Oxbow Books, Oxford, pp. 130-157.

Arthur, J. W. (2014). Culinary crafts and foods in southwestern Ethiopia: An ethnoarchaeological study of Gamo groundstones and pottery. African Archaeological Review 31: 131-168.

Ashley, C. Z. (2010). Towards a socialized archaeology of ceramics in 
Great Lakes Africa. African Archaeological Review 27: 135-163.

Atalay, S. (2005). Domesticating clay: The role of clay balls, mini balls, and geometric objects in daily life at Çatalhöyük. In Hodder, I. (ed.), Changing Materialities at Çatalhöyük: Reports from the 1995-1999 Seasons, Çatalhöyük Project, Vol. 5, McDonald Institute Monographs, British Institute of Archaeology at Ankara, Cambridge, pp. 221-284.

Atalay, S., and Hastorf, C. (2006). Food, meals, and daily activities: Food habitus at Neolithic Çatalhöyük. American Antiquity 71: 283-319.

Banducci, L. M. (2015). Fuel, cuisine and food preparation in Etruria and Latium: Cooking stands as evidence for change. In Spataro, M., and Villing, A. (eds.) (2015). Ceramics, Cuisine and Culture: The Archaeology and Science of Kitchen Pottery in the Ancient Mediterranean World, Oxbow Books, Oxford, pp. 157-169.

Ben-Shlomo, D., Shai, I., Zukerman, A., and Maeir, A. M. (2008). Cooking identities: Aegean-style cooking jugs and cultural interaction in Iron Age Philistia and neighboring regions. American Journal of Archaeology 112: 225-246.

Biskowski, M., and Watson, K. D. (2013). Changing approaches to maize preparation at Cerro Portezuelo. Ancient Mesoamerica 24: 213-223.

Black, S. L., and Thoms, A. V. (2014). Hunter-gatherer earth ovens in the archaeological record: Fundamental concepts. American Antiquity 79: 204-226.

Bolger, D., and Wright, R. P. (2013). Gender in southwest Asian prehistory. In Bolger, D. (ed.), A Companion to Gender Prehistory, John Wiley and Sons, Hoboken, NJ, pp. 372-394.

Bottéro, J. (2004). The Oldest Cuisine in the World: Cooking in Mesopotamia, University of Chicago Press, Chicago. 
Bourdieu, P. (1977). Outline of a Theory of Practice, Cambridge University Press, Cambridge.

Bray, T. L. (ed.) (2003a). The Archaeology and Politics of Food and Feasting in Early States and Empires, Kluwer Academic/Plenum Publishers, New York.

Bray, T. L. (2003b). Inka pottery as culinary equipment: Food, feasting, and gender in imperial state design. Latin American Antiquity 14: 3-28.

Bray, T. L. (2012). Ritual commensality between human and non-human persons: Investigating native ontologies in the late pre-Columbian Andean world. eTopoi. Journal for Ancient Studies 2: 197-212.

Briggs, R. V. (2015). The hominy foodway of the historic Native Eastern Woodlands. Native South 8: 112-146.

Broekmans, T., Adriaens, A., and Pantos, E. (2004). Analytical investigation of cooking pottery from Tell Beydar (NE-Syria). Nuclear Instruments and Methods in Physics Research B, 226: 92-97.

Brumfiel, E. M. (1991). Weaving and cooking: Women's production in Aztec Mexico. In Gero, J. M., and Conkey, M. (eds.), Engendering Archaeology: Women and Prehistory, Basil Blackwell, Oxford, pp. 224-251.

Brumfiel, E. M. (1998). Origins of social inequality. In Ember, C. R., Ember, M., and Peregrine, P. N. (eds.), Research Frontiers in Anthropology: Archaeology 1, Prentice Hall, Englewood Cliffs, NJ, pp. 3-20.

Brumfiel, E. M. (2013). The archaeology of gender in Mesoamerica: Moving beyond gender complementarity. In Bolger, D. (ed.) $A$ Companion to Gender Prehistory, John Wiley and Sons, Inc., Hoboken, NJ, pp. 564-583. 
Brumfiel, E. M., and Robin, C. (2008). Gender, households, and society: An introduction. In Robin, C., and Brumfiel, E. M. (eds.), Gender, Households, and Society: Unraveling the Threads of the Past and Present, Archeological Papers No. 18, American Anthropological Association, Washington, DC, pp. 1-16.

Capparelli, A., Pochettino, M. L., Lema, V., López, M. L., Andreoni, D., Ciampagna, M. L., and Carina, L. (2015). The contribution of ethnobotany and experimental archaeology to interpretation of ancient food processing: Methodological proposals based on the discussion of several case studies on Prosopis spp., Chenopodium spp. and Cucurbita spp. from Argentina. Vegetation History and Archaeobotany 24: 151-163.

Carretero, L. G., Wollstonecroft, M., and Fuller, D. Q. (2017). A methodological approach to the study of archaeological cereal meals: A case study at Çatalhöyük (Turkey). Vegetation History and Archaeobotany, online, pp. 1-19, doi 10.1007/s00334-017-0602-6.

Carroll, M. (2005). The preparation and consumption of food as a contributing factor towards communal identity in the Roman army. In Visy, Z. (ed.), Limes 19: Proceedings of the 19th International Congress of Roman Frontier Studies Held in Pécs, Hungary, September 2003, University of Pécs Press, Pécs, Hungary, pp. 363-372.

Cau Ontiveros, M. Á., Montana, G., Tsantini, E., and Randazzo, L. (2015). Ceramic ethnoarchaeometry in western Sardinia: Production of cooking ware at Pabillonis. Archaeometry 57: 453-475.

Chase, B. (2012). Crafting Harappan cuisine on the Saurashtran frontier of the Indus civilization. In Graff, S. R., and Rodríguez-Alegría, E. (eds.), The Menial Art of Cooking: Archaeological Studies of Cooking and Food Preparation, University Press of Colorado, Bouder, pp. 145-171.

Cheetham, D. (2010). Corn, colander, and cooking: Early maize processing in the Maya lowlands and its implications. In Staller, J. E., and Carrasco, M. (eds.), Pre-Columbian Foodways: Interdisciplinary 
Approaches to Food, Culture, and Markets in Ancient Mesoamerica, Springer, Berlin, pp. 345-368.

Chirikure, S. (2016). 'Ethno' plus 'archaeology': What's in there for Africa(ns)? World Archaeology 48: 693-699.

Clarke, M. J. (2001). Akha feasting: An ethnoarchaeological perspective. In Dietler, M., and Hayden, B. (eds.), Feasts: Archaeological and Ethnographic Perspectives on Food, Politics, and Power, Smithsonian Institution Press, Washington, DC, pp. 144-167.

Costin, C. L. (1991). Craft specialization: Issues in defining, documenting, and explaining the organization of production. In Schiffer, M. B. (ed.), Archaeological Method and Theory, Vol. 3, University of Arizona Press, Tuscon, pp. 1-56.

Costin, C. L. (2016). Who benefits? Structural change and lived experience in the late prehispanic Andes. In Hegmon, M. (ed.), Archaeology of the Human Experience, Archeological Papers No. 27, American Anthropological Association, Washington, DC, pp. 120-142.

Craig, O. E., Shillito, L.-M., Albarella, U., Viner-Daniels, S., Chan, B., Cleal, R., Ixer, R., Jay, M., Marshall, P., Simmons, E., Wright, E., and Pearson, M. P., (2015). Feeding Stonehenge: Cuisine and consumption at the Late Neolithic site of Durrington Walls. Antiquity 89: 347.

Cramp, L. J., Evershed, R. P., and Eckardt, H. (2011). What was a mortarium used for? Organic residues and cultural change in Iron Age and Roman Britain. Antiquity 85: 1339-1352.

Crenshaw, K. (1991). Mapping the margins: Intersectionality, identity politics, and violence against women of color. Stanford Law Review 43: 1241-1299.

Croucher, S. K. (2011). 'A concubine is still a slave': Sexual relations and Omani colonial identities in nineteenth-century East Africa. In Voss, B. 
L., and Casella, E. C. (eds.), The Archaeology of Colonialism: Intimate Encounters and Sexual Effects, Cambridge University Press, Cambridge, pp. 67-84.

Crown, P. L. (2000). Women's role in changing cuisine. In Crown, P. L. (ed.), Women and Men in the Prehispanic Southwest: Labor, Power and Prestige, School of American Research Press, Santa Fe, NM, pp. 226-266.

Crowther, A. (2012). The differential survival of native starch during cooking and implications for archaeological analysis. Archaeological and Anthropological Sciences 4: 221-235.

Cuéllar, A. M. (2013). The archaeology of food and social inequality in the Andes. Journal of Archaeological Research 21: 123-174.

Cummings, L. S. (2015). Phytolith analysis. In Metheny, K. B., and Beaudry, M. C. (eds.), Archaeology of Food: An Encyclopedia, Vol. 2, Rowman and Littlefield, New York, pp. 404-406.

Dawdy, S. L. (2010). "A wild taste": Food and colonialism in eighteenthcentury Louisiana. Ethnohistory 57: 389-414.

Day, P., Cau-Ontiveros, M. Á., Mas-Florit, C., and Müller, N. S. (2015). A contextual ethnography of cooking vessel production at Pòrtol, Mallorca (Balearic Islands). In Spataro, M., and Villing, A. (eds.), Ceramics, Cuisine and Culture: The Archaeology and Science of Kitchen Pottery in the Ancient Mediterranean World, Oxbow Books, Oxford, pp. 55-64.

de Certeau, M., Giard, L., and Mayol, P. (1998). The Practice of Everyday Life, Vol. 2, University of Minnesota Press, Minneapolis.

Deagan, K. (1974). Sex, Status, and Role in the Mestizaje of Spanish Colonial Florida, Ph.D. dissertation, Department of Anthropology, University of Florida, Gainesville. 
De León, J. P. (2009). Rethinking the organization of Aztec salt production: A domestic perspective. In Hirth, K. (ed.), Housework: Craft Production and Domestic Economy in Ancient Mesoamerica, Archeological Paper No. 19, American Anthropological Association, Washington, DC, pp. 45-57.

Deetz, K. F. (2015). Stolen bodies, edible memories: The influence and function of west African foodways in the early British Atlantic. In Helstosky, C. (ed.), The Routledge History of Food, Routledge Taylor and Francis Group, London, pp. 113-130.

deFrance, S. D. (2009). Zooarchaeology in complex societies: Political economy, status, and ideology. Journal of Archaeological Research 17: $105-168$.

Delgado, A., and Ferrer, M. (2011). Representing communities in heterogeneous worlds: Staple foods and ritual practices in the Phoenician diaspora. In Aranda-Jiménez, G., Montón-Subías, S., and SánchezRomero, M. (eds.), Guess Who's Coming To Dinner: Feasting Rituals in the Prehistoric Societies of Europe and the Near East, Oxbow Books, Oxford pp. 184-203.

Deori, B. G. (2016). Indigenous foodways of the Galos: A challenge to archaeology. Journal of Indo-Pacific Archaeology 37: 59-63.

Detienne, M. (1989). Culinary practices and the spirit of sacrifice. In Detienne, M., and Vernant, J.-P. (eds.), The Cuisine of Sacrifice Among the Greeks, University of Chicago Press, Chicago, pp. 1-20.

Dezendorf, C. (2013). The effects of food processing on the archaeological visibility of maize: An experimental study of carbonization of lime-treated maize kernels. Ethnobiology Letters 4: $12-20$.

Dietler, M. (2001). Theorizing the feast: Rituals of consumption, commensal politics, and power in African contexts. In Dietler, M., and 
Hayden, B. (eds.), Feasts Archaeological and Ethnographic Perspectives on Food, Politics, and Power, Smithsonian Institution Press, Washington, DC, pp. 65-114.

Dietler, M. (2010a). Archaeologies of Colonialism: Consumption, Entanglement, and Violence in Ancient Mediterranean France, University of California Press, Berkeley.

Dietler, M. (2010b). Cocina y colonialismo: Encuentros culinarios en la Francia mediterránea protohistórica. In Pareño, C. M., Jordà, G. P., and Sánchez, J. V. (eds.), De la cuina a la taula: IV Reunió d'Economia en el Primer Millenni aC., Universitat de Valencia, Saguntum, pp. 11-26.

Dietler, M. (2015). Rencontres culinaires: Colonialisme et la culture materielle incarnée. In Roure, R. (ed.), Contets acultrations en

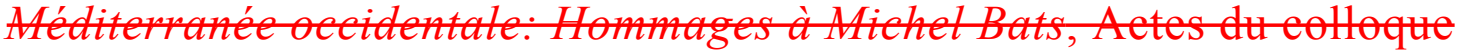
de Hyères, 1518 septembre 2011, Editions Errance, Paris, pp. 153159.

Dietler, M., and Hayden, B. (2001a). Digesting the feast: Good to eat, good to drink, good to think: An introduction. In Dietler, M., and Hayden, B. (eds.), Feasts: Archaeological and Ethnographic Perspectives on Food, Politics, and Power, Smithsonian Institution Press, Washington, DC, pp. 1-20.

Dietler, M., and Hayden, B. (eds.) (2001b). Feasts: Archaeological and Ethnographic Perspectives on Food, Politics, and Power, Smithsonian Institution Press, Washington, DC.

Dikomitou-Eliadou, M., Georgiou, A., and Vionis, A. K. (2016). Cooking fabric recipes: An interdisciplinary study of Cypriot cooking pots of the Late Bronze Age. Journal of Archaeological Science: Reports 7: 451-457.

Disspain, M. C., Ulm, S., Izzo, C., and Gillanders, B. M. (2016). Do fish remains provide reliable palaeoenvironmental records? An examination of the effects of cooking on the morphology and chemistry of fish otoliths, 
vertebrae and scales. Journal of Archaeological Science 74: 45-59.

Dixon, K. J., Novak, S. A., Robbins, G., Schablitsky, J. M., Scott, G. R., and Tasa, G. L. (2010). "Men, women, and children starving":

Archaeology of the Donner Family Camp. American Antiquity 75: $627-656$.

Dixon, K. J., Schablitsky, J. M., and Novak, S. A. (eds.) (2014). An Archaeology of Desperation: Exploring the Donner Party's Alder Creek Camp. University of Oklahoma Press, Norman.

Djordjević, B. (2016). The manufacture of traditional bread-baking pans: Ethnoarchaeology and the safeguarding of intangible heritage. In Biagetti, S., and Lugli, F. (eds.), The Intangible Elements of Culture in Ethnoarchaeological Research, Springer, Berlin, pp. 313-320.

Douglas, M. (1997). Deciphering a meal. In Counihan, C., and Van Esterik, P. (eds.), Food and Culture: A Reader, Routledge, New York, pp. $36-54$.

Dupont, F. (2015). Food, gender, and sexuality. In Wilkins, J., and Nadeau, R. (eds.), A Companion to Food in the Ancient World, John Wiley and Sons, West Sussex, UK, pp. 76-84.

Ebeling, J. R., and Rowan, Y. M. (2004). The archaeology of the daily grind: Ground stone tools and food production in the southern Levant. Near Eastern Archaeology 67: 108-117.

Ekroth, G. (2007). Meat in ancient Greece: Sacrificial, sacred or secular? Food and History 5: 249-272.

Ekroth, G., and Wallensten, J. (eds.) (2013). Bones, Behaviour and Belief: The Zooarchaeological Evidence as a Source for Ritual Practice in Ancient Greece and Beyond, Acta Instituti Atheniensis Regni Sueciae, Swedish Institute at Athens, Stockholm. 
Evershed, R. P. (2008). Organic residue analysis in archaeology: The archaeological biomarker revolution. Archaeometry 50: 895-924.

Faas, P. (2003). Around the Roman Table: Food and Feasting in Ancient Rome, Whiteside, S. Trans., University of Chicago Press, Chicago.

Fales, F. M., and Rigo, M. (2014). Everyday life and food practices in Assyrian military encampments. In Milano, L., and Bertoldi, F. (eds.), Paleonutrition and Food Practices in the Ancient Near East: Towards a Multidisciplinary Approach, History of the Ancient Near East Vol. 14, S.A.R.G.O.N. Editrice e Librería, Padova, Italy, pp. 413-437.

Fernandes, R., Meadows, J., Dreves, A., Nadeau, M.-J., and Grootes, P. (2014). A preliminary study on the influence of cooking on the $\mathrm{C}$ and $\mathrm{N}$ isotopic composition of multiple organic fractions of fish (mackerel and haddock). Journal of Archaeological Science 50: 153-159.

Fowles, S. M. (2008). Steps toward an archaeology of taboo. In Fogelin, L. (ed.), Religion, Archaeology, and the Material World, Occasional Paper, Vol. 36, Center for Archaeological Investigations, Southern Illinois University, Carbondale, pp. 15-37.

Fowles, S. M. (2013). An Archaeology of Doings: Secularism and the Study of Pueblo Religion, School for Advanced Research Press, Santa Fe, NM.

Gaillard, M., Morrison, K. D., and Whitehouse, N. (2015). Past anthropogenic land-use and land cover change at the global scale for climate modeling studies. Quarternary Perspectives 22: 25-27.

Gaspa, S. (2012). Meat offerings and their preparation in the state cult of the Assyrian empire. Bulletin of School of Oriental and African Studies 72: 249-273.

Gauss, W., Klebinder-Gauss, G., Kiriatzi, E., Pentedeka, A., and Georgakopoulou, M. (2015). Aegina: An important center of production 
of cooking pottery from the prehistoric to the historic era. In Spataro, M., and Villing, A. (eds.), Ceramics, Cuisine and Culture: The Archaeology and Science of Kitchen Pottery in the Ancient Mediterranean World, Oxbow Books, Oxford, pp. 65-90.

Geib, P. R., and Smith, S. J. (2008). Palynology and archaeological inference: Bridging the gap between pollen washes and past behavior. Journal of Archaeological Science 35: 2085-2101.

Geller, P. L. (2009). Identity and difference: Complicating gender in archaeology. Annual Review of Anthropology 38: 65-81.

Gero, J. M., and Conkey, M. W. (eds.) (1991). Engendering Archaeology: Women and Prehistory, Basil Blackwell, New York.

Gero, J. M. (2015). Yutopian: Archaeology, Ambiguity and the Production of Knowledge in Northwest Argentina, University of Texas Press, Austin.

Giddens, A. (1984). The Constitution of Society, University of California Press, Berkeley.

Gifford-Gonzalez, D. (2008). Thoughts on a method for zooarchaeological study of daily life. In Montón-Subías, S., and SánchezRomero, M. (eds.), Engendering Social Dynamics: The Archaeology of Maintenance Activities, BAR International Series, Vol. 1862, Archaeopress, Oxford, pp. 15-23.

Gokee, C. (2014). Crafting, cooking, and constructing histories: Women and the politics of everyday life along the Falémé River (ca. AD 1000-1900), Archaeological Review 31: 233-263.

Gokee, C., and Logan, A. L. (2014). Comparing craft and culinary practice in Africa: Themes and perspectives. African Archaeological Review 31: 87-104.

Goldstein, D. J., and Hageman, J. (2010). Power plants: Paleobotanical 
evidence of rural feasting in Late Classic Belize. In Staller, J. E., and Carrasco, M. (eds.), Pre-Columbian Foodways: Interdisciplinary Approaches to Food, Culture, and Markets in Ancient Mesoamerica, Springer, New York, pp. 421-440.

Goldstein, D. J., and Shimada, I. (2010). Feeding the fire: Food and craft production in the Middle Sicán period (AD 950-1050). In Klarich, E. (ed.), Inside Ancient Kitchens: New Directions in the Study of Daily Meals and Feasts, University Press of Colorado, Boulder, pp. 161-189.

González-Marcén, P., Montón-Subías, S., and Picazo, M. (2008). Towards an archaeology of maintenance activities. In Montón-Subías, S., and Sánchez-Romero, M. (eds.), Engendering Social Dynamics: The Archaeology of Maintenance Activities, BAR International Series, Vol. 1862, Archaeopress, Oxford, pp. 3-8.

Goody, J. (1994). Cooking, Cuisine and Class: A Study in Comparative Sociology, Cambridge University Press, Cambridge.

Graesch, A. P., DiMare, T., Schachner, G., Schaepe, D. M., and Dallen, J. (2014). Thermally modified rock: The experimental study of "firecracked" byproducts of hot rock cooking. North American Archaeologist 35: $167-200$.

Graff, S. R. (2012). Culinary preferences: Seal-impressed vessels from western Syria as specialized cookware. In Graff, S. R., and RodríguezAlegría, E. (eds.), The Menial Art of Cooking: Archaeological Studies of Cooking and Food Preparation, University Press of Colorado, Boulder, pp. 19-46.

Graff, S. R., and Rodríguez-Alegría, E. (eds.) (2012). The Menial Art of Cooking: Archaeological Studies of Cooking and Food Preparation, University Press of Colorado, Boulder.

Greenfield, H., and Bouchnick, R. (2011). Kashrut and Shechita: The relationship between dietary practices and ritual slaughtering of animals 
on Jewish identity. In Amundsen-Meyer, L., Engel, N., and Pickering, S. (eds.), Identity Crisis: Archaeological Perspectives on Social Identity, Proceedings of the 42nd Annual Chacmool Archaeology Conference, University of Calgary, Calgary, Alberta, Canada, pp. 106-120.

Grillo, K. M. (2014). Pastoralism and pottery use: An ethnoarchaeological study in Samburu, Kenya. African Archaeological Review 31: 105-130.

Gumerman IV, G. (2010). Big hearths and big pots: Moche feasting on the north coast of Peru. In Klarich, E. (ed.), Inside Ancient Kitchens: New Directions in the Study of Daily Meals and Feasts, University Press of Colorado, Boulder, pp. 111-131.

Gur-Arieh, S., Boaretto, E., Maeir, A., and Shahack-Gross, R. (2012). Formation processes in Philistine hearths from Tell es-Safi/Gath (Israel): An experimental approach. Journal of Field Archaeology 37: 121-131.

Gur-Arieh, S., Mintz, E., Boaretto, E., and Shahack-Gross, R. (2013). An ethnoarchaeological study of cooking installations in rural Uzbekistan: Development of a new method for identification of fuel sources. Journal of Archaeological Science 40: 4331-4347.

Haaland, R. (2012). Changing foodways as indicators of emerging complexity in Sudanese Nubia: From Neolithic agropastoralists to the Meroitic civilization. Azania 47: 327-343.

Halstead, P. (2012). Feast, food and fodder in Neolithic-Bronze Age Greece: Commensality and the construction of value. eTopoi. Journal for Ancient Studies 2: 21-51.

Halstead, P., and Isaakidou, V. (2011). Political cuisine: Rituals of commensality in the Neolithic and Bronze Age Aegean. In ArandaJiménez, G., Montón-Subías, S., and Sánchez-Romero, M. (eds.), Guess Who's Coming To Dinner: Feasting Rituals in the Prehistoric Societies of Europe and the Near East, Oxbow Books, Oxford, pp. 91-108. 
Hamilakis, Y. (2013). Archaeology and the Senses: Human Experience, Memory, and Affect, Cambridge University Press, New York.

Hamilakis, Y., and Harris, K. (2011). The social zooarchaeology of feasting: The evidence from the "ritual" deposit at Nopigeia-Drapanias. In Kapsomenos, E. G., Andreadaki-Vlazaki, M., Andrianakis, M., and Papadopoulou, E. (eds.), Proceedings of the 10th International Cretological Congress, Khania, 2011, Vol. 1, Fillologikos Syllogos Chrysostomos, Khania, Crete, pp. 225-244.

Hamilakis, Y. (2016). Decolonial archaeologies: From ethnoarchaeology to archaeological ethnography. World Archaeology 48: 678-682.

Hamon, C., and Le Gall, V. (2013). Millet and sauce: The uses and functions of querns among the Minyanka (Mali). Journal of Anthropological Archaeology 32: 109-121.

Hart, J. P., Lovis, W. A., Schulenberg, J. K., and Urquhart, G. R. (2007). Paleodietary implications from stable carbon isotope analysis of experimental cooking residues. Journal of Archaeological Science 34: 804-813.

Hastorf, C. A. (1991). Gender, space, and food in prehistory. In Gero, J. M., and Conkey, M. (eds.), Engendering Archaeology: Women and Prehistory, Basil Blackwell, Cambridge, pp. 132-159.

Hastorf, C. A. (2012a). The habitus of cooking practices at Neolithic Çatalhöyük. In Graff, S. R., and Rodríguez-Alegría, E. (eds.), The Menial Art of Cooking: Archaeological Studies of Cooking and Food Preparation, University Press of Colorado, Boulder, pp. 65-86.

Hastorf, C. A. (2012b). Steamed or boiled: Identity and value in food preparation. eTopoi. Journal for Ancient Studies 2: 213-242.

Hawkes, A. (2015). Fulachtaí fia and Bronze Age cooking in Ireland: Reappraising the evidence. Proceedings of the Royal Irish Academy 


\section{C: $1-31$.}

Hayashida, F. M. (2008). Ancient beer and modern brewers:

Ethnoarchaeological observations of chicha production in two regions of the north coast of Peru. Journal of Anthropological Archaeology 27: 161-174.

Hayden, B. (2014). The Power of Feasts: From Prehistory to the Present, Cambridge University Press, New York.

Hayden, B., and Villeneuve, S. (2011). A century of feasting studies. Annual Review of Anthropology 40: 433-439.

Hays-Gilpin, K. (2000). Feminist scholarship in archaeology. Annals, American Academy of Political and Social Sciences 571: 89-106.

Hegmon, M. (ed.) (2016a). Archaeology of the Human Experience, Archeological Paper No. 27, American Anthropological Association, Wiley, Hoboken, NJ.

Hegmon, M. (2016b). Archaeology of the human experience: An introduction. In Hegmon, M. (ed.), Archaeology of the Human Experience, Archeological Paper No. 27, American Anthropological Association, Wiley, Hoboken, NJ, pp. 7-21.

Hegmon, M., Ortman, S. G., and Mobley-Tanaka, J. L. (2000). Women, men, and the organization of space. In Crown, P. L. (ed.), Women and Men in the Prehispanic Southwest: Labor, Power, and Prestige, School of American Research Press, Santa Fe, NM, pp. 43-90.

Hein, A., Müller, N. S., and Kilikoglou, V. (2015). Heating efficiency of archaeological cooking vessels: Computer models and simulations of heat transfer. In Spataro, M., and Villing, A. (eds.), Ceramics, Cuisine and Culture: The Archaeology and Science of Kitchen Pottery in the Ancient Mediterranean World, Oxbow Books, Oxford, pp. 49-54. 
Heiss, A. G., Pouget N., Wiethold J., Delor-Ahu A., and Le Goff, I. (2015). Tissue-based analysis of a charred flat bread (galette) from a Roman cemetery at Saint-Memmie (Dep. Marne, Champagne-Ardenne, northeastern France). Journal of Archaeological Science 55: 71-82.

Heitman, C. C. (2016). "A mother for all the people": Feminist science and Chacoan archaeology. American Antiquity 81: 471-489.

Hendon, J. (2007). The engendered household. In Nelson, S. M. (ed.), Women in Antiquity: Theoretical Approaches to Gender and Archaeology, AltaMira Press, Lanham, MD, pp. 171-198.

Henry, A. G., Hudson, H. F., and Piperno, D. R. (2009). Changes in starch grain morphologies from cooking. Journal of Archaeological Science 36: 915-922.

Herbich, I., and Dietler, M. (2008). The long arm of the mother-in-law: Learning, postmarital resocialization of women, and material culture style. In Stark, M. T., Bowser, B. J., and Horne, L. (eds.), Cultural Transmission and Material Culture: Breaking Down Boundaries, University of Arizona Press, Tucson, pp. 223-244.

Holtzman, J. D. (2006). Food and memory. Annual Review of Anthropology 35: 361-378.

Homsey, L. K., Walker, R. B., and Hollenbach, K. D. (2010). What's for dinner? Investigating food processing technologies at Dust Cave, Alabama. Southeastern Archaeology 29: 182-196.

Hruby, J. (2008). You are how you eat: Mycenaean class and cuisine. In Hitchcock, L., Laffineur, R., and Crowley, J. L. (eds.), DAIS: The Aegean Feast, Vol. 29, Université de Liège, Liège, pp. 151-157.

Hruby, J. (2011). "It is very difficult to know people...": Cuisine and identity in Mycenaean Greece. In Amundsen-Meyer, L., Engel, N., and Pickering, S. (eds.), Identity Crisis: Archaeological Perspectives on 
Social Identity, University of Calgary, Calgary, Alberta, pp. 121-131.

Ikram, S. (1995). Choice Cuts: Meat Production in Ancient Egypt, Peeters Press, Leuven, Belgium.

Ingold, T. (1993). The temporality of the landscape. World Archaeology 25: $152-174$.

Iriarte, J., Gillam, J. C., and Marozzi, O. (2008). Monumental burials and memorial feasting: An example from the southern Brazilian highlands. Antiquity 82: 947-961.

Isaakidou, V. (2007). Cooking in the Labyrinth: Exploring 'cuisine' at Bronze Age Knossos. In Mee, C., and Renard, J. (eds.), Cooking up the Past: Food and Culinary Practices in the Neolithic and Bronze Age Aegean, Oxbow Books, Oxford, pp. 5-24.

Isbell, W. H., and Groleau, A. (2010). The Wari brewer woman: Feasting, gender, offerings, and memory. In Klarich, E. (ed.), Inside Ancient Kitchens: New Directions in the Study of Daily Meals and Feasts, University Press of Colorado, Boulder, pp. 191-219.

Jennings, J., Antrobus, K., Atencio, S., Glavich, E., Johnson, R., Loffler, G., Luu, C., Dietler, M., Hastorf, C., and Hayden, B. (2005). "Drinking beer in a blissful mood": Alcohol production, operational chains, and feasting in the ancient world. Current Anthropology 46: 275-303.

Jones, M. (2007). Feast: Why Humans Share Food, Oxford University Press, Oxford.

Jones, S. (2009). Food and Gender in Fiji: Ethnoarchaeological Explorations, Lexington Books, Lanham, MD.

Jones, S., and Quinn, R. (2010). Waitui Kei Vanua: Interpreting sea- and land-based foodways in Fiji. In VanDerwarker, A. M., and Peres, T. M. (eds.), Integrating Zooarchaeology and Paleoethnobotany: A 
Consideration of Issues, Methods, and Cases, Springer, Berlin, pp. 135-172.

Jones, S., Walsh-Haney, H., and Quinn, R. (2012). Kana Tamata or feasts of men: An interdisciplinary approach for identifying cannibalism in prehistoric Fiji. International Journal of Osteoarchaeology 25: 127-145.

Jordan, A. (2015). Spice island stew: Creolization of foodways on colonial era nutmeg plantations, Maluku Province, Indonesia. Journal of Indo-Pacific Archaeology 37: 33-48.

Joyce, R., and Henderson, J. S. (2007). From feasting to cuisine: Implications of archaeological research in an early Honduran village. American Anthropologist 109: 642-653.

Joyner, L. (2007). Cooking pots as indicators of cultural change: A petrographic study of Byzantine and Frankish cooking wares from Corinth. Hesperia: The Journal of the American School of Classical Studies at Athens 76: 183-227.

Junker, L. L., and Niziolek, L. (2010). Food preparation and feasting in the household and political economy of pre-Hispanic Philippine chiefdoms. In Klarich, E. (ed.), Inside Ancient Kitchens: New Directions in the Study of Daily Meals and Feasts, University Press of Colorado, Colorado, pp. 17-53.

Kelly, L. (2012). New flavors for the oldest recipes. Saudi Aramco World 63: $38-41$.

Kennedy, J. R. (2012). Commensality and labor in terminal Ubaid northern Mesopotamia. eTopoi. Journal for Ancient Studies 2: 125-156.

Kenoyer, M. J. (2000). Wealth and socioeconomic hierarchies of the Indus Valley civilization. In Richards, J., and Van Buren, M. (eds.), Order, Legitimacy, and Wealth in Ancient States, Cambridge University Press, Cambridge, pp. 88-109. 
Killgrove, K. (2016). Archaeologists draft ancient Chinese beer recipe. Forbes May 23.

Klarich, E. A. (ed.) (2010a). Inside Ancient Kitchens: New Directions in the Study of Daily Meals and Feasts, University Press of Colorado, Boulder.

Klarich, E. A. (2010b). Behind the scenes and into the kitchen: New directions for the study of prehistoric meals. In Klarich, E. (ed.), Inside Ancient Kitchens: New Directions in the Study of Daily Meals and Feasts, University Press of Colorado, Boulder, pp. 1-15.

Koca, Z. E. (ed.) (2015). Archaeological team prepares 4,000-year-old Hittite meals. Daily Sabah September 8.

Kooiman, S. (org.) (2017). Some like it hot: Analytic diversity and complementarity in the exploration of past cooking and cuisine. Symposium at the annual meeting of the Society for American Archaeology, Vancouver, Canada.

Koon, H. E., O'Connor, T. P., and Collins, M. J. (2010). Sorting the butchered from the boiled. Journal of Archaeological Science 37: 62-69.

Kuckelman, K. A. (2016). Cycles of subsistence stress, warfare, and population movement in the northern San Juan. In VanDerwarker, M. A., and Wilson, D. G. (eds.), The Archaeology of Food and Warfare: Food Insecurity in Prehistory, Springer, Berlin, pp. 107-132.

Kubiak-Martens, L., Brinkkemper, O., and Oudemans, T. F. (2015). What's for dinner? Processed food in the coastal area of the northern Netherlands in the Late Neolithic. Vegetation History and Archaeobotany 24: 47-62.

Lamb, J., and Loy, T. (2005). Seeing red: The use of Congo red dye to identify cooked and damaged starch grains in archaeological residues. Journal of Archaeological Science 32: 1433-1440. 
Langridge-Noti, E. (2015). Unchanging tastes: First steps towards the correlation of the evidence for food preparation and consumption in ancient Laconia. In Spataro, M., and Villing, A. (eds.), Ceramics, Cuisine and Culture: The Archaeology and Science of Kitchen Pottery in the Ancient Mediterranean World, Oxbow Books, Oxford, pp. 148-156.

LeCount, L. J. (2010). Maya palace kitchens. In Klarich, E. (ed.), Inside Ancient Kitchens: New Directions in the Study of Daily Meals and Feasts, University Press of Colorado, Boulder, pp. 133-160.

Lemonnier, P. (ed.) (1993). Technological Choices: Transformations in Material Cultures Since the Neolithic, Routledge, London.

Leroi-Gourhan, A. (1993). Le geste et la parole I and II: Gesture and Speech, trans. Berger, A. B., MIT Press, Cambridge.

Lewis, K. (2007). Fields and tables of Sheba: Food, identity, and politics in early historic southern Arabia. In Twiss, K. C. (ed.), The Archaeology of Food and Identity, Center for Archaeological Investigations, Southern Illinois University, Carbondale, pp. 192-217.

Lindenbaum, S. (2004). Thinking about cannibalism. Annual Review of Anthropology 33: 475-498.

Logan, A. L. (2016). An archaeology of food security in Banda, Ghana. In Hegmon, M. (ed.), Archaeology of the Human Experience, Archeological Paper No. 27, American Anthropological Association, John Wiley and Sons, Walden, MA, pp. 106-119.

Logan, A. L., and Cruz, M. D. (2014). Gendered taskscapes: Food, farming, and craft production in Banda, Ghana in the eighteenth to twenty-first centuries. African Archaeological Review 31: 203-231.

London, G. A. (2016). Ancient Cookware from the Levant: An Ethnoarchaeological Perspective, Worlds of the Ancient Near East and Mediterranean Series, Equinox, Sheffield, UK. 
Luley, B. P. (2014). Cooking, class, and colonial transformations in Roman Mediterranean France. American Journal of Archaeology 118: $33-60$.

Lyons, D. (2007). Integrating African cuisines: Rural cuisine and identity in Tigray, highland Ethiopia. Journal of Social Archaeology 7: 346-371.

Lyons, D. (2014). Perceptions of consumption: Constituting potters, farmers and blacksmiths in the culinary continuum in eastern Tigray, northern highland Ethiopia. African Archaeological Review 31: 169-201.

Magness, J. (2010). Early Islamic pottery: Evidence of a revolution in diet and dining habits? In Steadman, S., and Ross, J. C. (eds.), Agency and Identity in the Ancient Near East: New Paths Forward, Approaches to Anthropological Archaeology, Equinox, London, pp. 117-128.

Martin, L. (2000). Hunting, herding, feasting: Animal use at Neolithic Çatalhöyük, Turkey. Archaeology International 4: 39-42.

Masson, M. A. (1999). Animal resource manipulation in ritual and domestic contexts at Postclassic Maya communities. World Archaeology 31: $93-120$.

McCoy, P. C. (2011). Signs of a divine reality: The materiality of bird cook stones (Pōhaku 'Eho) from the dry interior uplands and mountainous regions of the island of Hawai'i. Hawaiian Archaeology 12: 65-107.

McGovern, P. E., and Hall, G. R. (2015). Charting a future course for organic residue analysis in archaeology. Journal of Archaeological Method and Theory 23: 592-622.

McGuire, R. H., and Van Dyke, R. M. (2008). Dismembering the trope: Imagining cannibalism in the ancient Pueblo world. In Nichols, D. L., and Crown, P. L. (eds.), Social Violence in the Prehispanic American Southwest, University of Arizona Press, Tucson, pp. 7-40. 
Mee, C., and Renard, J. (eds.) (2007). Cooking Up the Past: Food and Culinary Practices in the Neolithic and Bronze Age Aegean, Oxbow, Oxford.

Mentzer, S. (2012). Microarchaeological approaches to the identification and interpretation of combustion features in prehistoric archaeological sites. Journal of Archaeological Method and Theory, online, pp. 1-53, doi 10.1007/s10816-012-9163-2.

Meyers, C. (2008). Grinding to a halt: Gender and the changing technology of flour production in Roman Galilee. In Montón-Subías, S., and Sánchez-Romero, M. (2008). Engendering Social Dynamics: The Archaeology of Maintenance Activities, BAR International Series 1862, Archaeopress, Oxford, pp. 65-74.

Miller, C. (2015). Soil microtechniques. In Metheny, K. B., and Beaudry, M. C. (eds.), Archaeology of Food: An Encyclopedia, Vol. 2, Rowman and Littlefield, Denver, pp. 467-469.

Mills, B. J. (2004). Identity, Feasting, and the Archaeology of the Greater Southwest, University Press of Colorado, Boulder.

Mills, B. J. (2008). Colonialism and cuisine: Cultural transformation, agency, and history at Zuni Pueblo. In Horne, L., Bowser, B. J., and Stark, M. T. (eds.), Cultural Transmission and Material Culture: Breaking Down Boundaries, University of Arizona Press, Tucson, pp. 245-262.

Mintz, S. W., and Du Bois, C. M. (2002). The anthropology of food and eating. Annual Review of Anthropology 31: 99-119.

Mobley-Tanaka, J. L. (1997). Gender and ritual space during the pithouse to pueblo transition: Subterranean mealing rooms in the North American Southwest. American Antiquity 62: 437-448.

Monroe, J. C., and Janzen, A. (2014). The Dahomean feast: Royal women, private politics, and culinary practices in Atlantic West Africa. 
African Archaeological Review 31: 299-337.

Montón Subías, S. (2002). Cooking in zooarchaeology: Is this issue still raw? In Miracle, P., and Milner, N. (eds.), Consuming Passions and Patterns of Consumption, McDonald Institute for Archaeological Research, Cambridge, pp. 7-16.

Morrison, J. E., Sofianou, C., Brogan, T. M., Alyounis, J., and Mylona, D. (2015). Cooking up new perspectives for late Minoan IB domestic activities: An experimental approach to understanding the possibilities and probabilities of using ancient cooking pots. In Spataro, M., and Villing, A. (eds.), Ceramics, Cuisine and Culture: The Archaeology and Science of Kitchen Pottery in the Ancient Mediterranean World, Oxbow Books, Oxford, pp. 115-124.

Morrison, K. D. (2010). Dharmic projects, imperial reservoirs, and new temples of India: An historical perspective on dams in India.

Conservation and Society 8: 26-39.

Morrison, K. D. (2012). Great transformations: On the archaeology of cooking. In Graff, S. R., and Rodríguez-Alegría, E. (eds.), The Menial Art of Cooking: Archaeological Studies of Cooking and Food Preparation, University Press of Colorado, Bouder, pp. 231-244.

Morrison, K. D. (2016). From millets to rice (and back again?): Cuisine, cultivation, and health in early South India. In Shug, G. R., and Walimba, S. (eds.), A Companion to South Asia in the Past, Wiley Blackwell, New York, pp. 358-373.

Müller, N. S., Hein, A., Kilikoglou, V., and Day, P. (2013). Bronze Age cooking pots: Thermal properties and cooking methods. Préhistoires Méditerranéennes 4: 2-10.

Müller, N. S., Kilikoglou, V., and Day, P. (2015). Home-made recipes: Tradition and innovation in Bronze Age cooking pots from Akrotiri, Thera. In Spataro, M., and Villing, A. (eds.), Ceramics, Cuisine and 
Culture: The Archaeology and Science of Kitchen Pottery in the Ancient Mediterranean World, Oxbow Books, Oxford, pp. 37-48.

Nabil, A. (2015). The human aspect of technology: An ethnoarchaeological study of cooking ware from Jordan. Near Eastern Archaeology 78: 80-87.

Nash, D. J. (2010). Fine dining and fabulous atmosphere: Feasting facilities and political interaction in the Wari realm. In Klarich, E. (ed.), Inside Ancient Kitchens: New Directions in the Study of Daily Meals and Feasts, University Press of Colorado, Boulder, pp. 83-109.

Nelson, K. (2010). Environment, cooking strategies, and containers. Journal of Anthropological Archaeology 29: 238-247.

Nelson, S. M. (ed.) (2006). Handbook of Gender in Archaeology, AltaMira, Lanham, MD.

Nichols, D. L., and Crown, P. L. (eds.) (2008). Social Violence in the Prehispanic American Southwest, University of Arizona Press, Tucson.

Novak, S. A. (2014). [Wo]man and beast: Skeletal signatures of a starvation diet. In Dixon, K. J., Schablitsky, J. M., and Novak, S. A. (eds.), An Archaeology of Desperation: Exploring the Donner Party's Alder Creek Camp, University of Oklahoma Press, Norman, pp. 185-218.

Novak, S. A., and Kollmann, D. D. (2000). Perimortem processing of human remains among the Great Basin Fremont. International Journal of Osteoarchaeology 10: 65-75.

O'Conner, A. (2010). Maya foodways: A reflection of gender and ideology. In Staller, J. E., and Carrasco, M. (eds.), Pre-Columbian Foodways: Interdisciplinary Approaches to Food, Culture, and Markets in Ancient Mesoamerica, Springer, Berlin, pp. 487-510.

Olsson, M., and Isaksson, S. (2008). Molecular and isotopic traces of 
cooking and consumption of fish at an early medieval manor site in eastern middle Sweden. Journal of Archaeological Science 35: 773-780.

Otto, A. (2012). Defining and transgressing the boundaries between ritual commensality and daily commensal practices: The case of Late Bronze Age Tall Bazi. eTopoi. Journal for Ancient Studies 2: 179-195.

Øye, I. (2011). Food and technology: Cooking utensils and food processing in medieval Norway. In Klápšte, J., and Sommer, P. (eds.), Food in the Medieval Rural Environment: Processing, Storage, Distribution of Food, Brepols, Brussels, pp. 225-234.

Papadopoulou, E., and Prévost-Dermarkar, S. (2007). 'Il n'y a pas de cuisine sans feu': Une approche des techniques culinaires au Néolithique et à l'Âge du Bronze Ancien à travers les structures de combustion en Gréce du Nord. In Mee, C., and Renard, J. (eds.), Cooking up the Past. Food and Culinary Practices in the Neolithic and Bronze Age Aegean, Oxbow Books, Oxford, pp. 123-135.

Papaefthymiou, A., Pilali, A., and Papadopoulou, E. (2007). Les installations culinaires dans un village du Bronze Ancien en Grèce du Nord: Archontiko Giannitsa. In Mee, C., and Renard, J. (eds.) (2007). Cooking Up the Past: Food and Culinary Practices in the Neolithic and Bronze Age Aegean, Oxbow Books, Oxford, pp. 136-147.

Pauketat, T. R., Kelly, L. S., Fritz, G. J., Lopinot, N. H., Elias, S., and Hargrave, E. (2002). The residues of feasting and public ritual at early Cahokia. American Antiquity 67: 257-279.

Paulette, T., and Fisher, M. (2014). Brewing beer in Mesopotamia: Technology, technique, and tradition. Paper presented at the American Anthropological Association Annual Meeting, Washington, DC.

Pecci, A., Burri, S., Durand, A., Inserra, F., and Cau Ontiveros, M. Á. (2016). Residue analysis of the floors of a charcoal burner's hut at Naour (Morocco). In Biagetti, S., and Lugli, F. (eds.), The Intangible Elements 
of Culture in Ethnoarchaeological Research, Springer, Berlin, pp. 253-261.

Pecci, A., Cau Ontiveros, M. Á., Valdambrini, C., and Inserra, F. (2013). Understanding residues of oil production: Chemical analyses of floors in traditional mills. Journal of Archaeological Science 40: 883-893.

Pecci, A., Gabrieli, R. S., Inserra, F., Cau, M. A., and Waksman, S. Y. (2015). Preliminary results of the organic residue analysis of 13th century cooking wares from a household in Frankish Paphos (Cyprus). Science and Technology of Archaeological Research 1: 99-105.

Pérez, V. R., Nelson, B., and Martin, D. L. (2008). Veneration or violence? A study of variation in human bone modification at La Quemada. In Nichols, D. L., and Crown, P. L. (eds.), Social Violence in the Prehispanic American Southwest, University of Arizona Press, Tuscon, pp. 123-142.

Peyronel, L., and Spreafico, G. (2008). Food processing in the Levant during the Middle Bronze Age: Fire installations, cooking pots and grinding tools at Tell Mardikh-Ebla (Syria): Two case studies. In Fiorentino, G., and Magri, D. (eds.), Charcoals from the Past: Cultural and Palaeoenvironmental Implications: Proceedings of the Third International Meeting of Anthracology, Cavallino-Lecce (Italy), June 28th-July 1st 2004, BAR International Series 1807, Archaeopress, Oxford, pp. 213-223.

Pezzarossi, G., Kennedy, R., and Law, H. (2012). "Hoe cake and pickerel": Cooking traditions, community, and agency at a nineteenthcentury Nipmuc farmstead. In Graff, S. R., and Rodríguez-Alegría, E. (eds.), The Menial Art of Cooking: Archaeological Studies of Cooking and Food Preparation, University Press of Colorado, Bouder, pp. 201-229.

Pfälzner, P. (2007). Archaeological investigations in the royal palace of Qatna. In Bonacossi, D. M. (ed.), Urban and Natural Landscapes of an 
Ancient Syrian Capital. Settlement and Environment at Tell

Mishrifeh/Qatna and in Central-Western Syria, Vol. 1, Studi Archeologici Su Qatna, Udine, pp. 29-64.

Pfälzner, P. (2012). How did they bury the kings of Qatna? In Pfälzner, P., Niehr, H., Pernicka, E., and Wissing, A. (eds.), (Re-)Constructing Funerary Rituals in the Ancient Near East, Proceedings of the First International Symposium of the Tübingen Post-Graduate School "Symbols of the Dead" in May 2009, Qatna Studien, University of Tübingen, Harrassowitz, Wiesbaden, pp. 205-220.

Pfälzner, P., Niehr, H., Pernicka, E., and Wissing, A. (2012). (Re-)Constructing Funerary Rituals in the Ancient Near East, Proceedings of the First International Symposium of the Tübingen PostGraduate School "Symbols of the Dead" in May 2009, Qatna Studien, University of Tübingen, Harrassowitz, Wiesbaden.

Picazo, M. (2008). Greek terracotta figurines: Images and representations of everyday life. In Montón-Subías, S., and Sánchez-Romero, M. (eds.), Engendering Social Dynamics: The Archaeology of Maintenance Activities, BAR International Series 1862, Archaeopress, Oxford, pp. $57-63$.

Pitock, T. (2015). A scientist walks into a bar...What happens when genome mapping meets the ancient craft of brewing? Discover, October: $36-41$.

Pollock, S. (2012). Between feasts and daily meals. Towards an archaeology of commensal spaces. eTopoi. Journal for Ancient Studies 2: $1-20$.

Popkin, P. R. (2013). Hittite animal sacrifice: Integrating zooarchaeology and textual analysis. In Ekroth, G., and Wallensten, J. (eds.), Bones, Behavior and Belief. The Zooarchaeological Evidence as a Source for Ritual Practice in Ancient Greece and Beyond, Acta Instituti Atheniensis Regni Sueciae Series IN 4 ${ }^{\circ}, 55$, Swedish Institute at Athens, Stockholm, 
pp. 101-114.

Potter, J. M. (2010). Making meals (matter). In Klarich, E. (ed.), Inside Ancient Kitchens: New Directions in the Study of Daily Meals and Feasts, University Press of Colorado, Boulder, pp. 241-251.

Preston-Werner, T. (2008). Breaking down binaries: Gender, art, and tools in ancient Costa Rica. In Brumfiel, E., and Robin, C. (eds.), Gender, Households, and Society: Unraveling the Threads of the Past and the Present, Archeological Papers No. 18, American Anthropological Association, Washington, DC, pp. 49-59.

Raviele, M. E. (2011). Experimental assessment of maize phytolith and starch taphonomy in carbonized cooking residues. Journal of Archaeological Science 38: 2708-2713.

Reddy, S. N. (2015). Feeding family and ancestors: Persistence of traditional Native American lifeways during the Mission period in coastal Southern California. Journal of Anthropological Archaeology 37: 48-66.

Restelli, F. B., and Mori, L. (2014). Bread, baking moulds and related cooking techniques in the Ancient Near East. Food and History 12: $39-55$.

Robb, J., Elster, E. S., Isetti, E., Knüsel, C. J., Tafuri, M. A., and Traverso, A. (2015). Cleaning the dead: Neolithic ritual processing of human bone at Scaloria Cave, Italy. Antiquity 89: 39-54.

Robin, C. (2006). Gender, farming, and long-term change: Maya historical and archaeological perspectives. Current Anthropology 47: 409-433.

Roddick, A. P., and Hastorf, C. A. (2010). Tradition brought to the surface: Continuity, innovation and change in the Late Formative period, Taraco Peninsula, Bolivia. Cambridge Archaeological Journal 20: $157-178$. 
Rodríguez-Alegría, E. (2005). Eating like an Indian: Negotiating social relations in the Spanish colonies. Current Anthropology 46: 551-573.

Rodríguez-Alegría, E. (2012). From grinding corn to dishing out money: A long-term history of cooking in Xaltocan, Mexico. In Graff, S. R., and Rodríguez-Alegría, E. (eds.), The Menial Art of Cooking: Archaeological Studies of Cooking and Food Preparation, University Press of Colorado, Bouder, pp. 99-118.

Rodríguez-Alegría, E., and Graff, S. R. (2012). Introduction: The menial art of cooking. In Graff, S. R., and Rodríguez-Alegría, E. (eds.), The Menial Art of Cooking: Archaeological Studies of Cooking and Food Preparation, University Press of Colorado, Bouder, pp. 1-18.

Rodríguez-Alegría, E., and Stoner, W. D. (2016). The trade in cooking pots under the Aztec and Spanish empires. Ancient Mesoamerica 27: 197-207.

Roffet-Salque, M., Dunne, J., Altoft, D. T., Casanova, E., Cramp, L. J., Smyth, J., Whelton, H., and Evershed, R. P. (in press). From the inside out: Upscaling organic residue analyses of archaeological ceramics. Journal of Archaeological Science: Reports.

Rothschild, N. A. (2015). Women in Spanish colonial contexts. In Funari, P. P., and Senatore, M. X. (eds.), Archaeology of Culture Contact and Colonialism in Spanish and Portuguese America, Springer, Berlin, pp. 183-198.

Rotroff, S. I. (2015). The Athenian kitchen from the Early Iron Age to the Hellenistic period. In Spataro, M., and Villing, A. (eds.), Ceramics, Cuisine and Culture: The Archaeology and Science of Kitchen Pottery in the Ancient Mediterranean World, Oxbow Books, Oxford, pp. 180-189.

Roumpou, M., Psaraki, K., Aravantinos, V., and Heron, C. (2007). Early Bronze Age cooking vessels from Thebes: Organic residue analysis and archaeological implications In Mee, C., and Renard, J. (eds.), Cooking up 
the Past: Food and Culinary Practices in the Neolithic and Bronze Age Aegean, Oxbow Books, Oxford, pp 158-173.

Rova, E. (2014). Tannurs, tannur concentrations and centralised bread production at Tell Beydar and elsewhere: An overview. In Milano, L., and Bertoldi, F. (eds.), Paleonutrition and Food Practices in the Ancient Near East: Towards a Multidisciplinary Approach, S.A.R.G.O.N., Padova, pp. 121-170.

Rowan, Y. M. (2011). Beyond belief: The archaeology of religion and ritual. In Rowan, Y. M. (ed.), Beyond Belief: The Archaeology of Religion and Ritual, Archeological Papers No. 21, American Anthropological Association, Washington, DC, pp .1-10.

Russell, N. (2011). Social Zooarchaeology: Humans and Animals in Prehistory, University of Cambridge Press, Cambridge.

Russell, N. (2015). Food and ritual. In. Metheny, K. B., and Beaudry, M. C. (eds.), Archaeology of Food: An Encyclopedia, Vol. 1, Rowman and Littlefield, New York, pp. 197-199.

Russell, N., and Bogaard, A. (2010). Subsistence actions at Çatalhöyük. In Steadman, S., and Ross, J. C. (eds.), Agency and Identity in the Ancient Near East: New Paths Forward, Equinox, London, pp. 63-79.

Russell, N., and Martin, L. (2012). Cooking meat and bones at Neolithic Çatalhöyük. In Graff, S. R., and Rodríguez-Alegría, E. (eds.), The Menial Art of Cooking: Archaeological Studies of Cooking and Food Preparation, University Press of Colorado, Bouder, pp. 87-98.

Sabban, F. (2015). The ideological foundations of the food culture of preImperial China. In Wilkins, J., and Nadeau, R. (eds.), Companion to Food in the Ancient World, Wiley Blackwell, Hoboken, pp. 393-402.

Sallaberger, W. (2012). Home-made bread, municipal mutton, royal wine: Establishing social relations during the preparation and consumption of 
food in religious festivals at Late Bronze Age Emar. eTopoi. Journal for Ancient Studies 2: 157-177.

Samuel, D. J. (2013). Who made bread, and how, at Amarna? Akhetaten Sun 19: 2-7.

Scaramelli, K. T. de (2008). Coffee, tea, or chicha? Commensality and culinary practice in the Middle Orinoco following colonial contact. In Martinez, A. R. (ed.), Descencuentros culturales: una mirada desde la cultura material de las Américas, Cuadernos de Arqueología Mediterránea, Vol. 17, Portico Librerias, S.A., Barcelona, pp. 53-71.

Scaramelli, K. T. de, and Scaramelli, F. (2012). Cooking for fame or fortune: The effect of European contact on casabe production in the Orinoco. In Graff, S. R., and Rodríguez-Alegría, E. (eds.), The Menial Art of Cooking: Archaeological Studies of Cooking and Food Preparation, University Press of Colorado, Bouder, pp. 119-144.

Schucany, C. (2005). Cooking like a native, dining like a Roman: Food preparation and consumption in Roman Switzerland. In Carroll, M., Hadley, D. M., and Willmott, H. (eds.), Consuming Passions: Dining from Antiquity to the Eighteenth Century, Tempus, Stroud, pp. 39-48.

Simmons, A. (2012). A foodways research recipe. Australasian Historical Archaeology 30: 43-51.

Simms, S. R., Berna, F., and Bey III, G. J. (2013). A prehispanic Maya pit oven? Microanalysis of fired clay balls from the Puuc region, Yucatan, Mexico. Journal of Archaeological Science 40: 1144-1157.

Skibo, M. J. (2015). Pottery use-alteration analysis. In Marreiros, M. J., Gibaja Bao, F. J., and Ferreira Bicho, N. (eds.), Use-Wear and Residue Analysis in Archaeology, Springer, Berlin, pp. 189-198.

Smith, M. L. (2006). The archaeology of food preference. American Anthropologist 108: 480-493. 
Smith, S. T. (2003). Pharaohs, feasts, and foreigners: Cooking, foodways, and agency on ancient Egypt's southern frontier. In Bray, T. L. (ed.), The Archaeology and Politics of Food and Feasting in Early States and Empires, Kluwer Academics/Plenum Publishers, New York, pp. 39-64.

Smogorzewska, A. (2012). Fire installations in household activities: Archaeological study from Tell Arbid (north-east Syria). Paléorient 38: 227-247.

Solari, A., Olivera, D., Gordillo, I., Bosch, P., Fetter, G., Lara, V. H., and Novelo, O. (2015). Cooked bones? Method and practice for identifying bones treated at low temperature. International Journal of Osteoarchaeology 25: 426-440.

Sophronidou, M., and Tsirtsoni, Z. (2007). What are the legs for? Vessels with legs in the Neolithic and Early Bronze Age. In Mee, C., and Renard, J. (eds.), Cooking up the Past: Food and Culinary Practices in the Neolithic and Bronze Age Aegean, Oxbow Books, Oxford, pp. 247-269.

Spataro, M., and Villing, A. (eds.) (2015). Ceramics, Cuisine and Culture: The Archaeology and Science of Kitchen Pottery in the Ancient Mediterranean World, Oxbow Books, Oxford.

Stahl, A. B. (2005). Introduction: Changing perspectives on Africa's pasts. In Stahl, A. B. (ed.), African Archaeology: A Critical Introduction, Wiley-Blackwell, Hoboken, NJ, pp. 1-17.

Stahl, A. B. (2014). Intersections of craft and cuisine: Implications for what and how we study. African Archaeological Review 31: 383-393.

Staller, J. E. (2010). Ethnohistoric sources on foodways, feasts, and festivals in Mesoamerica. In Staller, J. E., and Carrasco, M. (eds.), PreColumbian Foodways: Interdisciplinary Approaches to Food, Culture, and Markets in Ancient Mesoamerica, Springer, Berlin, pp. 23-69.

Stein, G. (2012). Food preparation, social context, and ethnicity in a 
prehistoric Mesopotamian colony. In Graff, S. R., and Rodríguez-Alegría, E. (eds.), The Menial Art of Cooking: Archaeological Studies of Cooking and Food Preparation, University Press of Colorado, Bouder, pp. 47-64.

Sunseri, C. K. (2015). Food politics of alliance in a California frontier Chinatown. International Journal of Historical Archaeology 19: 416-431.

Swenson, E. (2015). The archaeology of ritual. Annual Review of Anthropology 44: 329-345.

Symanski, L. C., and Gomes, D. M. (2015). Material culture, mestizage, and social segmentation in Santarém, northern Brazil. In Funari, P. P., and Senatore, M. X. (eds.), Archaeology of Culture Contact and Colonialism in Spanish and Portuguese America, Springer, New York, pp. 199-217.

Tallet, P. (2015). Food in ancient Egypt. In Wilkins, J., and Nadeau, R. (eds.), A Companion to Food in the Ancient World, John Wiley and Sons, Hoboken, NJ, pp. 319-325.

Thomas, R. I. (2014). Portable stoves and braziers in terracotta. In Villing, A., Bergeron, M., Bourogiannis, G., Johnston, A., Leclere, F., and Masson, A. (eds.), Naukratis: Greeks in Egypt, British Museum, London, pp. 1-5.

Thoms, A. V. (2008). The fire stones carry: Ethnographic records and archaeological expectations for hot-rock cookery in western North America. Journal of Anthropological Archaeology 27: 443-460.

Tsoukala, V. (2009). Cereal processing and the performance of gender in archaic and classical Greece: Iconography and function of a group of terracotta statuettes and vases. In Aygün, Ç. Ö. (ed.), SOMA 2007: Proceedings of the XI Symposium on Mediterranean Archaeology, Istanbul Technical University, 24-29 April 2007, BAR International Series 1900, Archaeopress, Oxford, pp. 387-395.

Tsukimoto, A. (2010). Peace for the dead: On kispu(m) again. Orient 45: 
$101-110$.

Tuma, M. W. (2006). Ethnoarchaeology of subsistence behaviours within a rural African American community: Implications for interpreting vertebrate faunal data from slave quarters areas of antebellum plantation sites. Historical Archaeology 40: 1-26.

Twiss, K. C. (2008). Transformations in an early agricultural society: Feasting in the southern Levantine Pre-Pottery Neolithic. Journal of Anthropological Archaeology 27: 418-442.

Twiss, K. C. (2012a). The archaeology of food and social diversity. Journal of Archaeological Research 20: 357-395.

Twiss, K. C. (2012b). The complexities of home cooking: Public feasts and private meals inside the Çatalhöyük house. eTopoi. Journal for Ancient Studies 2: 53-73.

Um, N. (2003). Spatial negotiations in a commercial city: The Red Sea port of Mocha, Yemen, during the first half of the eighteenth century. The Journal of the Society of Architectural Historians 62:178-193.

Urem-Kotsou, D., and Kotsakis, K. (2007). Pottery, cuisine and community in the Neolithic of north Greece. In Mee, C., and Renard, J. (eds.), Cooking up the Past: Food and Culinary Practices in the Neolithic and Bronze Age Aegean, Oxbow Books, Oxford, pp. 225-246.

Valenzuela-Lamas, S., Valenzuela-Suau, L., Saula, O., Colet, A., Mercadal, O., Subiranas, C., and Nadal, J. (2014). Shechita and kashrut: Identifying Jewish populations through zooarchaeology and taphonomy: Two examples from medieval Catalonia (northeastern Spain). Quaternary International 330: 109-117.

Van De Mieroop, M. (1999). The Ancient Mesopotamian City, Oxford University Press, Oxford. 
VanDerwarker, A. M., Bardolph, D. N., Hoppa, K. M., Thakar, H. B., Martin, L. S., Jaqua, A. L., Biwer, M. E., and Gill, K. M. (2016). New World paleoethnobotany in the new millennium (2000-2013). Journal of Archaeological Research 24: 125-177.

VanDerwarker, A. M., and Detwiler, K. R. (2002). Gendered practice in Cherokee foodways: A spatial analysis of plant remains from the Coweeta Creek site. Southeastern Archaeology 21: 21-28.

VanDerwarker, A. M., and Wilson, G. D. (2015). The Archaeology of Food and Warfare: Food Insecurity in Prehistory, Springer, Berlin.

Villing, A., and Spataro, M. (2015). Investigating ceramics, cuisine and culture: Past, present and future. In Spataro, M., and Villing, A. (eds.), Ceramics, Cuisine and Culture: The Archaeology and Science of Kitchen Pottery in the Ancient Mediterranean World, Oxbow Books, Oxford, pp $1-25$.

Vokaer, A. (2010). Cooking wares in ancient Syria (first to 10th centuries AD): Reconstructing the production contexts from the consumption sites. Archaeometry 52: 605-627.

Voss, B. L. (2008). Domesticating imperialism: Sexual politics and the archaeology of empire. American Anthropologist 110: 191-203.

Walker, P. L. (2001). A bioarchaeological perspective on the history of violence. Annual Review of Anthropology 30: 573-596.

Warinner, C., and Tuross, N. (2009). Alkaline cooking and stable isotope tissue-diet spacing in swine: Archaeological implications. Journal of Archaeological Science 36: 1690-1697.

Whitbread, I. (2015). Materials choices in utilitarian pottery: Kitchen wares in the Berbati Valley, Greece. In Spataro, M., and Villing, A. (eds.), Ceramics, Cuisine and Culture: The Archaeology and Science of Kitchen Pottery in the Ancient Mediterranean World, Oxbow Books, Oxford, pp. 
$28-36$.

White, C. E., and Ketchum, S. A. (orgs.) (2014). The "hidden intelligence" of kitchens: Techniques and traditions of making meals. Symposium at the annual meeting of the American Anthropological Association, Washington, DC.

Whitley, J., and Boileau, M.-C. (2015). True grit: Production and exchange of cooking wares in the 9th-century BC Aegean. In Spataro, M., and Villing, A. (eds.), Ceramics, Cuisine and Culture: The Archaeology and Science of Kitchen Pottery in the Ancient Mediterranean World, Oxbow Books, Oxford, pp. 75-90.

Wilson, G. D., and VanDerwarker, A. M. (2015). The functional dimensions of earth oven cooking: An analysis of an accidently burned maize roast at the C. W. Cooper site in west-central Illinois. Journal of Field Archaeology 40: 166-175.

Winther-Jacobsen, K. (2015). Cooking wares between the Hellenistic and Roman world: Artefact variability, technological choice and practice. In Spataro, M., and Villing, A. (eds.), Ceramics, Cuisine and Culture: The Archaeology and Science of Kitchen Pottery in the Ancient Mediterranean World, Oxbow Books, Oxford, pp. 91-102.

Wright, J. C. (2004). The Mycenaean Feast, American School of Classical Studies at Athens, Athens.

Wright, K. I. (2014). Domestication and inequality? Households, corporate groups and food processing tools at Neolithic Çatalhöyük. Journal of Anthropological Archaeology 33: 1-33.

Wylie, A. (2002). Thinking from Things, University of California Press, Berkeley.

Yang, X., Yu, J., Lü, H., Cui, T., Guo, J., and Ge, Q. (2009). Starch grain analysis reveals function of grinding stone tools at Shangzhai site, 
Beijing. Science in China Series D-Earth Sciences 52: 1164-1171.

Bibliography of Recent Literature

Aldeias, V., Gur-Arieh, S., Maria, R., Monteiro, P., and Cura, P. (2016).

Shell we cook it? An experimental approach to the microarchaeological record of shellfish roasting. Archaeological and Anthropological

Sciences, online, pp. 1-19, doi:10.1007/s12520-016-0413-1.

Allison, P. M. (2009). Understanding Pompeian household practices through their material culture. FACTA: A Journal of Roman Material Culture Studies 3: 11-32.

Allred, L. (2011). The kitchen at Garšana. In Owen, D. (ed.), Garšana Studies, Vol. 6, Cornell University Studies in Assyriology and Sumerology, CDL Press, Bethesda, MD, pp. 11-29.

Amundsen-Meyer, L., Engel, N., and Pickering, S. (eds.) (2011). Identity Crisis: Archaeological Perspectives on Social Identity, Proceedings of the 42nd Annual Chacmool Archaeology Conference, University of Calgary, Calgary, Alberta, Canada.

Becker, K. (ed.). (2012). Studia alimentorum 2003-2013: une décennie de recherche, Food and History 10.2, Brepols, Brussels.

Briggs, R. V. (2016). The civil cooking pot: Hominy and the Mississippian standard jar in the Black Warrior Valley, Alabama. American Antiquity 81: 316-332.

Capparelli, A., Valamoti, M. S., and Wollstonecroft, M. M. (2011). After the harvest: Investigating the role of food processing in past human societies. Archaeological and Anthropological Science 3: 1-5.

Claassen, C. (2010). Feasting with Shellfish in the Southern Ohio Valley: Archaic Sacred Sites and Rituals, University of Tennessee Press, Knoxville. 
Claflin, K. W., and Scholliers, P. (2013). Writing Food History: A Global Perspective, Bloomsbury, London.

Crane, E. E. (1999). The World History of Beekeeping and Honey Hunting, Routledge, New York.

Crown, P. L., Emerson, T. E., Gu, J., Hurst, W. J., Pauketat, T. R., and Ward, T. (2012). Ritual black drink consumption at Cahokia. Proceedings of the National Academy of Sciences USA 109: 13,944-13,949.

Curtis, R. J. (2001). Ancient Food Technology, Technology and Change in History Vol. 5, Brill, Leiden.

Daviau, P. M., Hasan, J. K., and Cowell, L. (2016). Traditional methods of cooking: The evidence from ethnography and experimental archaeology. In Daviau, P. M., Battenfield, J. R., Ellis, S., and Popkin, P. R. (eds.), Excavations at Tall Jawa Jordan, Culture and History of the Ancient Near East, Vol. 5, Brill, Leiden, pp. 462-478.

Detienne, M., and Vernant, J.-P. (eds.) (1989). The Cuisine of Sacrifice Among the Greeks, University of Chicago Press, Chicago.

Dietler, M. (2007). Culinary encounters: Food, identity, and colonialism. In Twiss, K. C. (ed.), The Archaeology of Food and Identity, Occasional Paper No. 34, Center for Archaeological Investigations, Southern Illinois University, Carbondale, pp. 218-242.

Eusebio, M. S., and Jordan, A. (2015). Beyond subsistence: Food and foodways in Indo-Pacific archaeology. Journal of Indo-Pacific Archaeology 37: 1-3.

Fentress, E. (2010). Cooking pots and cooking practice: An African BainMarie? Papers of the British School at Rome 78: 145-150.

Foxhall, L. (2007). Olive Cultivation in Ancient Greece, Oxford University Press, Oxford. 
Goldstein, R. C. (2008). Hearths, grinding stones, and households: Rethinking domestic economy in the Andes. In Brumfiel, E., and Robin, C. (eds.) Gender, Households, and Society: Unraveling the Threads of the Past and the Present, Archeological Papers No. 18, American Anthropological Association, Washington, DC, pp. 37-48.

Gremillion, K. J. (2011). Ancestral Appetites: Food in Prehistory, Cambridge University Press, Cambridge.

Gumerman IV, G. (1997). Food and complex societies. Journal of Archaeological Method and Theory 4: 105-139.

Halstead, P., and Barrett, J. C. (eds.) (2004). Food, Cuisine and Society in Prehistoric Greece, Oxbow Books, Oxford.

Hastorf, C. A. (2017). The Social Archaeology of Food: Thinking about Eating from Prehistory to the Present, Cambridge University Press, Cambridge.

Heath, D., and Meneley, A. (2007). Techne, technoscience, and the circulation of comestible commodities: An introduction. American Anthropologist 109: 593-602.

Helstosky, C. (ed.) (2015). The Routledge History of Food, Routledge Taylor and Francis, London.

Jackson, H. E., Scarry, M., and Scott, S. L. (2016). Domestic and ritual meals in the Moundville chiefdom: Patterns of plant and animal use at the Moundville center and its outlying communities. In Steponaitis, V., and Scarry, M. (eds.), Rethinking Moundville and Its Hinterland, University Press of Florida, Gainesville, pp. 187-233.

Karageorghis, V., and Kouka, O. (eds.) (2010). On Cooking Pots, Drinking Cups, Loomweights and Ethnicity in Bronze Age Cyprus and Neighbouring Regions, An International Archaeological Symposium held in Nicosia, November 6th-7th 2010, A.G. Leventis Foundation, Nicosia, 


\section{Cyprus.}

Kaufman, C. K. (2006). Cooking in Ancient Civilizations, Greenwood Press, Westport, CT.

Kelly, S. E., and Ardren, T. (eds.) (2016). Gendered Labor in Specialized Economies: Archaeological Perspectives on Female and Male Work, University Press of Colorado, Boulder.

Kerner, S., Chou, C., and Warmind, M. (2015). Commensality: From Everyday Food to Feast, Bloomsbury, London.

Klápšte, J., and Sommer, P. (eds.) (2011). Food in the Medieval Rural Environment: Processing, Storage, Distribution of Food, Ruralia 8, Brepols, Turnhout, Belgium.

Kwak, S., and Marwick, B. (2015). What did they cook? A preliminary investigation into culinary practices and pottery use in the central part of the Korean Peninsula during the mid to late Holocene. Journal of IndoPacific Archaeology 37: 25-32.

Metheny, K. B., and Beaudry, M. C. (2015). Archaeology of Food: An Encyclopedia, Vol. 1-2, Rowman and Littlefield, Lanham, MD.

Milano, L., and Bertoldi, F. (eds.) (2014). Paleonutrition and Food Practices in the Ancient Near East: Towards a Multidisciplinary Approach, History of the Ancient Near East, Vol. 14, S.A.R.G.O.N., Padova.

Montón-Subías, S., and Sánchez-Romero, M. (eds.) (2008). Engendering Social Dynamics: The Archaeology of Maintenance Activities, BAR International Series 1862, Archaeopress, Oxford.

Morrison, J. E. (2015). The Art and Archaeology of Cooking: A Comparative Study of Late Minoan Cook-Pots from Mochlos and Papadiokambos, Ph.D. dissertation, School of Archaeology and Ancient 
History, University of Leicester, Leicester, UK.

Moss, M. L., and Cannon, A. (eds.) (2011). The Archaeology of North Pacific Fisheries, University of Alaska Press, Fairbanks.

Peres, T. M. (2017). Foodways archaeology: A decade of research from the southeastern United States. Journal of Archaeological Research 25, in press.

Reitz, E. J., Andrus, C. F., and Sandweiss, D. H. (2008). Ancient fisheries and marine ecology of coastal Peru. In Rick, T. C., and Erlandson, J. (eds.), Human Impacts on Ancient Marine Ecosystems: A Global Perspective, University of California Press, Berkeley, pp. 125-146.

Rumold, C. U. (2010). Illuminating Women's Work and the Advent of Plant Cultivation in the Highland Titicaca Basin of South America: New Evidence from Grinding Tool and Starch Grain Analysis, Ph.D. dissertation, Department of Anthropology, University of California, Santa Barbara.

Saberi, H. (2011). Cured, Smoked, and Fermented: Proceedings of the Oxford Symposium on Food and Cooking, Prospect Books, Devon, UK.

Staller, J. E., and Carrasco, M. (eds.) (2010). Pre-Columbian Foodways: Interdisciplinary Approaches to Food, Culture, and Markets in Ancient Mesoamerica, Springer, New York.

Singer, A. (2005). Serving up charity: The Ottoman public kitchen. The Journal of Interdisciplinary History 35: 481-500.

Symons, M. (2004). A History of Cooks and Cooking, University of Illinois Press, Champaign.

Vanderwarker, A. M., and Peres, T. M. (eds.) (2010). Integrating Zooarchaeology and Paleoethnobotany: A Consideration of Issues, Methods, Cases, Springer, New York. 
Voorhies, B., and Martínez-Tagüeña, N. (2016). Clamming up: An ethnoarchaeological study of a Costa Rican artisanal clam fishery. The Journal of Island and Coastal Archaeology, 1-23. http://www.tandfonline.com/doi/full/10.1080/15564894.2016.1262483, retrieved December 2016.

Walker, B. J., DeVries, B., LaBianca, Ø. S., Avissar, M., Khalaf, M. A., Salem, H., Gabrieli, R. S. (2009). Reflections of empire: Archaeological and ethnographic studies on the pottery of the Ottoman Levant. The Annual of the American Schools of Oriental Research 64: 1-163.

Wilkins, J., and Nadeau, R. (eds.) (2015). A Companion to Food in the Ancient World, Wiley Blackwell, Oxford. 